\title{
ORBÁN JÁNOS
}

\section{Teleki Sámuel marosvásárhelyi könyvtáráról és gyüjteményeiről ${ }^{*}$}

\begin{abstract}
A kapuit 1802-ben Marosvásárhelyen megnyitó Teleki Téka a maga korában a magyar nyelvterület egyik legfontosabb könyvtára volt. Jelentősége talán a leginkább nyilvános jellegében állt: alapítója, gróf Teleki Sámuel kezdettől fogva a legszélesebb olvasóközönségnek szánta, és ennek megfelelően gyüjtötte hat évtizeden át, vagyonát nem kímélve, a halálakor több tízezer tételre rúgó állományt. A könyvek értéke hosszú ideig tompította az épület kvalitásai iránti érdeklődést, valamint a további, muzeális jellegű gyüjtemények iránti érdeklődést, pedig a könyvtár becsét a pompás csarnok, a szobrok, a portrék és a galérián rejlö ásványok is növelték. Az alábbi közlemény mindezt együtt szeretné ismertetni.
\end{abstract}

\section{Az alapitó és a könyvtár}

A könyvtárat létrehozó gróf Teleki Sámuel (1739-1822) Erdély egyik legjelentősebb foúri családjának sarja (1. kép). Nagyapja Teleki Mihály, az Erdélyi Fejedelemség Habsburg-integrációját előkészítő 17. századi államférfi, apja Teleki Sándor guberniumi tanácsos, az erdélyi református kollégiumok és peregrinus diákok bőkezü támogatója - a családi hagyományt tehát erősen meghatározta a Habsburg-pártiság és a református identitás. Sámuel 1759-1763 közötti európai tanulmányútja során Bázel, Utrecht, Leiden és Párizs egyetemeit látogatta, föként a természettudományok és matematika neves tudósainak előadásait hallgatva. A peregrináció nemcsak tanulása, hanem bibliofil múveltsége kialakulása szempontjából is kulcsfontosságú volt. Az első indíttatásokat Christoph Jakob Beck (1711-1785) bázeli

* Írásunk eredetileg olaszul jelent meg Biblioteca e collezioni di Sámuel Teleki a Marosvásárhely címmel, a nemzetközi olvasóközönség számára foglalva össze a Teleki Tékára vonatkozó mủvészettörténeti kutatások 2016-os állását. Az összegzés magyar nyelvü változatát a $M a-$ gyar Könyvszemle szerkesztőinek megtisztelő felkérésére tesszük közzé, a kutatási eredmények további népszerüsítésének céljával. Megjegyezzük, hogy az építéstörténetet és a portrékat tárgyaló fejezetek részletesebb közlemények formájában magyarul korábban már napvilágot láttak, ezekre a megfelelő helyeken utalunk majd. Az alábbi szöveg szinte azonos az olasz változattal, ám a könyvészetét helyenként kiegészítettük magyar tételekkel, illetve a gyüjteményekről szóló fejezetekbe beemeltünk néhány, az olasz változatban kevésbé relevánsnak ítélt, terjedelmi okokból mellőzött levéltári adatot és meglátást. 


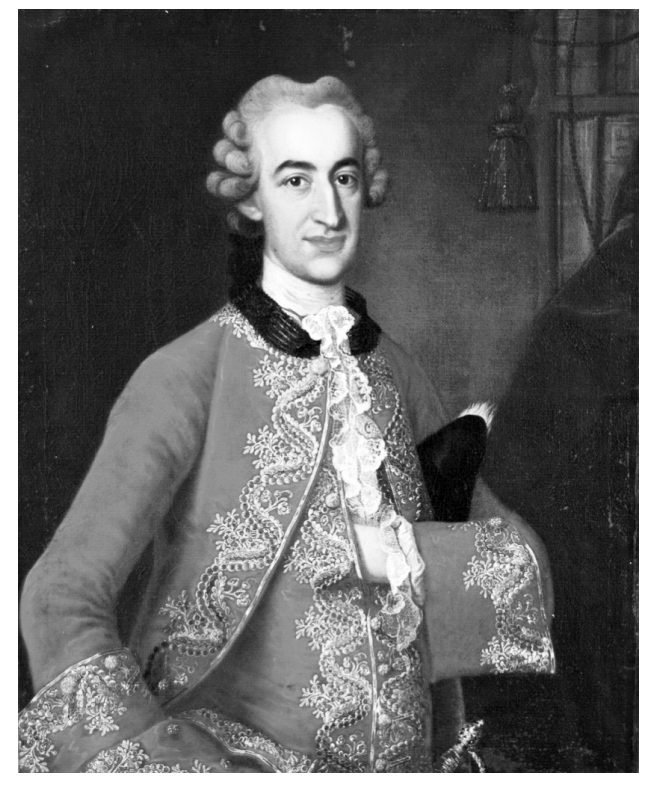

1. kép

Johann Michael Millitz: Teleki Sámuel, 1766

professzortól, az ottani könyvtár őrétől kapta, ezt követően utazása során mindenhol kiemelt figyelmet szentelt a könyvtáraknak, majd több ezer forint értékben vásárolt, több ládányi könyvvel tért haza. ${ }^{1}$ Ekkor döbbent rá igazán hazája müvelődési viszonyainak fejletlenségére, és ez sarkallta arra, hogy a könyvtárát hozzáférhetővé tegye az erdélyi olvasók számára. Gesztusában tehát nyilvánvaló a modernizációs szándék, esetünkben az ismeretekhez való hozzáférés lehetőségeinek kiszélesítése révén, mely Európa keleti felén a hazájuk elmaradottságára rádöbbenő felvilágosult elméket oly gyakran fütötte ekkoriban.

Pályájának alakulása szerencsés módon lehetőséget is nyújtott célja megvalósítására. 1774-ben Küküllő vármegye főispánjává, 1777-ben az Erdélyi Nagyfejedelemséget irányító Gubernium tanácsosává nevezték ki. A református Teleki karrierlehetőségei II. József trónra léptét követően még inkább kiszélesedtek, hiszen az új császár reformpolitikájának megvalósításában már vallási elöítéletek nélkül támaszkodott a rátermett erdélyi föurakra: 1785-ben a birodalom közigazgatási átszervezésével létrehozott nagyváradi császári kerület főbiztosa, 1787-től pedig erdélyi udvari alkancellár lett Bécsben. 1791-től az újra önállósuló Erdélyi Kancelláriát vezette - ezzel pályája csúcsára ért, az Erdélyi Nagyfejedelemség legfelsőbb közjogi tisztségét töltötte be. Élete utolsó három és fél évtizedében ennek megfelelően Bécsben élt. De ez alatt sem tévesztette szem elöl könyvtára gyarapítását. Így vall erről katalógusa első kötetében: „,De ezeknek a közhivataloknak gondjai közepette sem mulasztottam el egyetlen helyet, egyetlen alkalmat sem, hogy egész Európából könyveket vásárolva könyvtáram állományát szaporítsam, és sem az életem viszontagságai, sem a távolság és egyéb nehézségek nem akadályoztak meg abban, hogy sokszor erőmön és anyagi lehetőségeimen, tehetségemen felül költséget fordítsak Bibliothecám gyarapítására. Mikor ezt tettem, szándékom az volt, hogy hazámban a könyvek hiányán könnyítsek."2

A birodalmi fóváros környezete kiváló lehetőséget kínált az erdélyi fớur szá-

${ }^{1}$ DeÉ Nagy Anikó, A könyvtáralapitó Teleki Sámuel, Kolozsvár, Erdélyi Múzeum-Egyesület, 1997, 158-166.

2 A könyvtárkatalógus első kötetében található szöveget fordításban közli: Teleki Sámuel és a Teleki Téka, szerk. Deé Nagy Anikó, Bukarest, Kriterion, 1976, 213. 
mára a nyugati világot behálózó könyvgyüjtő hálózat kiépítésére, melyet személyesen irányított, a vásárlásokról ő maga döntött. ${ }^{3} \mathrm{~A}$ Teleki Téka fö sajátossága, hogy kezdettől fogva nyilvános, mindenki számára hozzáférhető intézményként müködött, emellett tanúskodik az épület térszerkezetének kialakítása, az alapító levelezése, valamint az általa kibocsátott rendszabályok: „A könyvtár és a múzeum a tudomány müvelőinek és azoknak, akik látogatni óhajtják, meghatározott napokon és órákon legyen nyitva, a könyvek az igénylőknek egyenként adassanak ki" - rendelte el 1798-ban. ${ }^{4}$ A széles körü használatot segítette a gyüjtemény négykötetes katalógusa is. ${ }^{5} \mathrm{~A}$ gyüjtés ennek megfelelően enciklopédikus jellegü volt, igyekezett minél több tudományterület kortárs irodalmát lefedni, kiemelt hangsúlyt fektetve az Erdélyben nehezebben hozzáférhető kiadványokra, a történeti irodalomra, a felvilágosodás korát meghatározó reáltudományok különféle ágaira stb. A gyüjtemény értékes részét képezték a görög-római klasszikusok, de nem elhanyagolható a kancellár felesége, iktári Bethlen Zsuzsanna tekintélyes magyar könyvgyüjteménye sem. Bár a könyvtár céljai szempontjából nem jelentettek prioritást, Teleki természetesen könyvritkaságokat is vásárolt, amit incunabulumok, editio princepsek, nyomdászati és könyvtörténeti különlegességek sora jelez. ${ }^{6}$ A műértők érdeklődését nyilván ezek váltották ki leginkább, ezt tükrözi a Tékát 1816-ban meglátogató Kazinczy Ferenc (1759-1831) beszámolója is, aki Bodoni-kiadványokra, Piranesi-metszetekre, a Museum Pio Clementinumra, a herculaneumi régiségek kiadványaira és természetesen a Corvinákra hívta fel többek között a figyelmet. ${ }^{7}$

A páratlan mủvelödési lehetöséggel a megnyitást követő évtizedekben élt is Marosvásárhely közönsége, a rendszeres használat legalábbis erről tanúskodik. Az 1803 júliusától kezdődő olvasónapló szerint naponta 1-3 fô látogatta, évente pedig mintegy 25-30 személy. Ez a szám az alapító haláláig fokozatosan növekedett: 1812-1813-ban már nem ritkán a napi 6-8 fôt is elérte a látogatottság, egész évben pedig 64 fó volt. ${ }^{8}$ Azonban a kancellár leszármazottai sajnálatos módon nem fordítottak gondot a megfelelő kezelésére, halálát követően leállt a könyv-

${ }^{3}$ DeÉ NAgy 1997, i. m. 168-169.

${ }^{4}$ Tabula legum bibliothecariarum. Közli: Bibliothecae Samuelis S. R. I. Com. Teleki de Szék Pars secunda, Viennae, typis Mathiae Andreae Schmidt, 1800, VII-XII.

5 A kéziratban maradt ötödik kötet Deé Nagy Anikó jóvoltából 2002-ben látott napvilágot. Bibliothecae Samuelis Com. Teleki de Szék Pars Quinta, libros inde ab anno MDCCCXIX post typis vulgatam catalogi partem quartam comparatam complexa, ed. Deé Nagy Anikó, Budapestini, Novi Forum Siculorum, Bibliotheca Nationalis Hungariae, Bibliotheca Teleki-Bolyai, 2002.

${ }^{6}$ DeÉ Nagy 1997, i. m. 192-224.

7 Kazinczy Ferencz eredeti munkái, Második kötet, Utazások, a M.T.T. megbízásából összeszedék: Bajza és Schedel, Buda, a Magyar Kir. Egyetem betüivel, 1839, 205. - A Teleki Tékában valójában csak egy Corvina létezett, ma már sajnos ez sincs a gyüjteményben, vö. DeÉ NAGY 1997 , i. m. 219.

${ }^{8}$ SomkútI Gabriella, Egy XVIII. századi föúri könyvtár olvasóforgalma a múlt század elsö felében = Az Országos Széchényi Könyvtár Évkönyve 1961-1962, 291-302. 
beszerzés, a gyűjjtemény pedig egyre inkább könyvmúzeummá dermedt a 19. század folyamán.

\section{Az épület ${ }^{9}$}

A könyvtárnak a kancellár Marosvásárhelyen, a felesége nagynénjétől, Wesselényi Katától örökölt, L alaprajzú, egyemeletes barokk lakóház U alaprajzúvá bővítése révén teremtett otthont $1799-1802$ között. ${ }^{10}$ Az ily módon bővített épület kettős funkciót látott el: a meglévő rész továbbra is lakóházként müködött, a barokk városi palota összes tartozékával (piano nobile, díszterem, háztartási helyiségek), köztük a kancellár emeleti lakosztályával, melynek hálószobájából jellemző módon a könyvtár galériájára lehetett kijutni. De az új szárny földszintjét a nyilvános könyvtár helyiségei uralták: a könyvek tárolására szolgáló nagyterem mellett itt kapott helyet a nyilvános olvasóterem és a könyvtáros lakosztálya.

A könyvtár fö ékességét képező nagyterem egyemeletes, háromhajós, boltozott csarnok, melynek szabadon hagyott középhajóját pillérsorok határolják, oldalain köröskörül kovácsoltvas mellvédekkel ellátott galéria húzódik. Az elöször egy szűkebb előtérbe érkező látogató előtt a középhajó tengelyében nyíló ajtón belépve tárul fel az impozáns tér látványa. A könyveket a falak mentén és a pillérek körül elhelyezett eredeti szekrényekben tárolják mind a mai napig, látványuk nagyban hozzájárul a tér ünnepélyességéhez. A szárnyat egyik oldalról az U alaprajzú épület udvara, a másik oldalról egy díszkert határolta. A terem már a kortársak tetszését is elnyerte, ,,az építömester értelemmel, s nagy szerencsével tette a rajzolatot" - nyilatkozta róla Kazinczy. ${ }^{11}$

De kik is voltak ezek az építőmesterek? Erdemes a kérdést alaposabban megvizsgálni, hiszen az építéstörténet nem lokális jelentőségü, a könyvtárépítészet aktuális európai kérdéseire reflektál. ${ }^{12}$ A tervezés kiindulópontját Ernest Koch (1755-1785) bécsi építőmester 1797-es tervrajza képezte, melyen a könyvtárterem kétszintes terét két hosszanti pillérsor osztja. Azonban még nem utal a terem jellegét ma meghatározó szabadon hagyott, kétszintes középhajóra, helyén

${ }^{9}$ A fejezet alapja: OrBÁn János, „... kétfelöl galériája lesz, a közepe pedig templom formára felmegyen." A Teleki Téka hosszházas terveiről = Táguló horizont, Tanulmányok a fiatal müvészettörténészek marosvásárhelyi konferenciájának előadásaiból, szerk. Kovács Zsolt, Orbán János, Marovásárhely, Kolozsvár, Maros Megyei Múzeum, Erdélyi Múzeum-Egyesület, Entz Géza Mủvelődéstörténeti Alapítvány, 2013, 91-109.

${ }^{10}$ A ház történetéröl: ORBÁn János, ,, Mert Könyvet lehetne arról írni sokat ... tsak a' míg épített ólly'fényes Házakat." Wesselényi Kata marosvásárhelyi házáról = Dolgozatok az Erdélyi Múzeum Érem- és Régiségtárából, Új sorozat 6-7(2011-2012), 265-286.

${ }^{11}$ Kazinczy Ferenc, Erdélyi Cancellárius Gróf Teleki Sámuel Excell. Bibliothecája Maros-Vásárhelytt = Tudományos Gyüjtemény, 7(1817), 4.

12 A hosszházas tervekről és analógiáikról részletesebben lásd ORBÁn 2013, i. m. 91-109. 
a földszinten boltozatokat jelöl: Koch tehát pillérsorokkal osztott, ámde különálló szinteket tervezett, melyek főként tároló helyként szolgáltak volna. Mindez érthető is, hiszen a Téka nyilvános könyvtárnak épült, széles gyüjtőkörrel, folyamatosan növekvő állománnyal, az észszerü megoldás tehát nem a reprezentatív, hanem a tárolás szempontjából jól kihasználható tér lett volna. A raktár-könyvtár („Magazinbibliothek”) a könyvmennyiség növekedésével a 19. századi könyvtárépítészet nagy kihívása lett, de már a Téka tervezése idején jelen volt az építészeti gondolkodásban. A fejlődés a továbbiakban a raktárak, olvasótermek és hivatali helyiségek teljes szétválása fele mozdult el.

Felmerül a kérdés, hogy Koch terve hogyan alakult át, föként annak ismeretében, hogy a továbbiakban három építőmester is megjelent az építkezésen. A marosvásárhelyi Türk Antal 1797 nyarán átdolgozta Koch tervét, ezen azonban még nem jelenik meg egyértelműen a szabadon hagyott középhajó. Annál nyilvánvalóbb viszont az 1798-ban elhunyt Türk helyére érkezö Ignatz Schlaff 1799-es tervén. Az építés utóbbi alapján kezdődött el, ám a források egyelöre nem adnak választ arra a kérdésre, hogy a reprezentatív csarnok ötlete Türk, Schlaff, vagy pedig a tervezés folyamatát élénk érdeklődéssel követő megrendelő invenciója volt-e. Mindenesetre végül a hagyományosabb, látványosabb változat valósult meg, felülírva a korábbi, funkcionálisabb javaslatot. Az építőtelepről 1800-ban távozó Schlaff helyét a tordai Követsi János vette át, és ő fejezte be 1802-ben az építkezést, ámde különösebb beleszólása már nem lehetett a terv alakulásába.

A megvalósult hosszházas tér tipológiailag jól beleilleszthető az európai könyvtárépítészet fejlődési folyamatába. A nyomtatás elterjedésével növekvő könyvmennyiség egyre célszerübb, a könyvekhez való hozzáférést és a tárolást szolgáló megoldásokat követelt, ez pedig kedvezett a különféle tértípusok létrejöttének, mint a körüljáró erkéllyel ellátott, vagy a szabadon álló oszlopokra terhelt karzattal kialakított terem. Ezeknek számtalan példája idézhető a barokk építészetből, főként a kolostorkönyvtárak világából. Gyakran bukkannak fel kéthajós terek is. Sajátos csoport a 18. században osztrák területen az ún. kupolás könyvtáraké (Kuppelbibliotheken), melyek megoldásai föként a bécsi Hofbibliothek hatására vezethetőek vissza.

A Teleki Téka háromhajós, galériás csarnoka azonban tipológiailag csak távolról kötődik mindezekhez. A könyvtártermek hármas osztásának ötlete már a 15. századi Itáliában felbukkant, gondolunk itt a Michelozzo által a firenzei San Marco kolostor számára épített háromhajós megoldásra (1438), vagy Novello Malatesta cesenai könyvtárára (1447-1452). A hajókat elválasztó oszlopsorok mindkettőben erőteljes hangsúlyt adtak a hosszanti tengelynek. ${ }^{13}$ Ám a Téka valódi rokonait a 18. század könyvtárai között érdemes keresnünk. Nagy Péter cár 1718-tól kezdte el Szentpéterváron a „Kayserliche Kunstkammer und Bibliothek” névvel illetett együttes építését. Toronyszerü középrésze csillagvizsgálónak adott otthont, két oldalához egy-egy szimmetrikus alaprajzi elrendezésü, háromszintes szárny csatlakozott: egyikben a könyvtár, a másikban a Kunstkammer gyüjtemé-

\footnotetext{
${ }_{13}$ Pevsner, Nikolaus, The History of Building Types, London, Thames and Hudson, 1976, 94-95.
} 
nyei kaptak helyet. A könyvtár a második és harmadik emeleten elegáns, a földszinten dór, az emeleten füzérdíszes jónfejezetek által osztott, galériás csarnokot foglalt magába. ${ }^{14}$ 1795-ben II. Katalin cárnő is emeltetett Szentpéterváron egy hasonló könyvtárat. ${ }^{15} \mathrm{~A}$ Teleki Téka igen közeli rokona a weimari hercegi könyvtár Rokokó Termének háromhajós, galériás, pillérsorokkal tagolt csarnoka (17611766). A középhajó rövidebb oldalainak homorú lezárása itt ovális alapformát, egyben erős centralizáló hangsúlyt eredményezett, mindez egy újabb szinttel is kiegészült a manzárdban. A földszinten pillérekkel, az emeleten jón oszlopokkal tagolt, háromhajós, kétszintes csarnok Ochsenhausen (Baden-Württenberg, Oberschwaben) bencés kolostorának könyvtárterme is (1785-1791), a könyvszekrények hajdan itt is a falak mentén, illetve a pillérek körül helyezkedtek el.

Johann Friedrich Penther 1748-ban adta ki Anleitung zur bürgerlichen Baukunst címủ építészeti traktátusának IV. kötetét, melyben az uralkodói rezidencia kontextusában a könyvtár épületét is tárgyalta. A rezidencia részét képező, ám szinte teljesen különálló, kétemeletes épület közepére a könyvtáros szobáit, jobbra és balra egy-egy azonos alaprajzi elrendezésü, oszlopsoros galériával kialakított, háromhajós szárnyat javasolt. Mindez számos hasonlóságot mutat Nagy Péter szentpétervári könyvtárával, maga Penther is utal arra, hogy ismerte azt. ${ }^{16}$ Népszerü traktátusa bizonyára befolyásolta a továbbiakban a könyvtárépítészetet is, ám hogy mennyire számolhatunk Penther közvetlen hatásával Marosvásárhelyen, az egyelöre nem világos. Teleki könyvtárában a tervezés időszakában munkája mindenesetre már megvolt.

Az itt bemutatott háromhajós, galériás könyvtártermek csoportja tipológiailag határozottan eltér a teremkönyvtár különféle változataitól, a kupolás könyvtáraktól, valamint a kéthajós elrendezéstől, indokolt tehát külön típusként való kezelésük - a templomépítészetből kölcsönzött kifejezéssel élve nevezhetnénk őket akár csarnokkönyvtáraknak is. Az ilyenfajta könyvtártér a jelek szerint a 18. században vált ismertté, így az ide sorolható emlékek fokozottan magukon viselik a kor klasszicizálódó építészeti formanyelvét. Néhány háromhajós példával a 19. század első felének kiforrott klasszicista építészetében is találkozunk, gondolunk itt a bécsi Schottenstift bencés apátság termére (1835), vagy az edinburgh-i egyetemi könyvtárra (1831-1834).

Végezetül szót kell még ejtenünk azokról a sajátos, nyolcszög alaprajzú könyvtártervekről, melyeket Bécsben készített egy, a Képzőművészeti Akadémián tanuló erdélyi építésznövendék, Ugrai László (1769-1830). A Teleki Téka

${ }^{14}$ BeCKer, Regina, Theorie und Praxis - zur Typologie in der Bibliotheksarchitektur des 17. und 18. Jahrhunderts = Ikonographie der Bibliotheken: Vorträge eines bibliotheks-historischen Seminars vom 13. bis 14. September 1988 in der Herzog-August-Bibliothek, hrsg. von Carsten-Peter Warncke, Wiesbaden, Harrassowitz, 1992, 242.

${ }^{15}$ Alaprajzát és metszetét közli: Edwards, Edward, Memoirs of Libraries. Including a Handbook of Library-Economy, Volume II, London, Leipzig, Trübner Co., F. A. Brockhaus, 1859, 687-690.

16 Penther, Johann Friedrich, Vierter Theil der ausführlichen Anleitung zur Bürgerlichen Bau-Kunst... Augspurg, 1748, 24-25, Tab. XI, XVI. 
forrásanyagában két változatban fennmaradt rajzot azonban, ha a helyszíni adottságokat tekintjük, aligha szánhatták kivitelre. Bár nem volt gyakorlati szerepük az építkezésben, mégis jelentősek számunkra, hiszen a centrális alaprajzú, önálló könyvtár problematikáját emelik be, ha csak elméleti szinten is, a marosvásárhelyi tervezés folyamatába. A centrális könyvtár típusa az újkori Európában a 'bibliotheca publica' eszményének, az egyetemes emberi tudás tárházának ideális építészeti kifejezőjeként a traktátusirodalomban gyakran felbukkan, de számos esetben épültek is ilyenek, a legismertebb példák a 18. században Wolfenbüttel könyvtára (1705-1713) és az oxfordi Radcliffe Camera (1737-1749). ${ }^{17}$

\section{A portrégyüjtemény ${ }^{18}$}

A portrégyüjtemény kezdettől a könyvtár berendezésének szerves részét képezte, egységes jellege azonban az utókor tudatában elhalványult, a festmények többsége elkallódott. Ez a körülmény a gyüjtemény eredeti összetételének rekonstruálását tette a kutatás elsődleges feladatává. Erre nézve Kelemen Márton könyvtáros 1826. október 15-én kelt leírása tekinthető a legmegbízhatóbb forrásnak. Négy évvel Teleki Sámuel halála után készült, az életében kialakult gyüjtemény végleges összetételét mutatja tehát be, szerzője pedig a helyszín legjobb ismerője volt. ${ }^{19}$

Kelemen két helyszínen vette számba a portrékat: a nagy könyvtárcsarnokban, valamint annak előterében. A nagyteremben a bejárattal szembeni föhelyet a kancellár impozáns, egész alakos portréja foglalta el, átellenben, a bejárat fölötti déli mellvéden nagyapja, Teleki Mihály arcmása függött. A középhajó nyugati oldalán a pillérekre rögzítve, északról dél fele haladva Teleki Sámuel ifjúkori portréja, Festetics György, Széchényi Ferenc és Brukenthal Sámuel erdélyi gubernátor, a keleti oldalon pedig, szintén dél fele haladva Bethlen Zsuzsanna, a könyvtáralapító felesége, Bethlen Gábor erdélyi fejedelem, Hunyadi Mátyás magyar király és Savoyai Jenő arcképe kapott helyet. Az emeleti galérián a folyosóról nyíló ajtó fölött Teleki József koronaőr, a fegyveres szobába vezető ajtó fölött pedig Batthyány Ignác erdélyi püspök portréja függött. Végül a földszinten, a galéria alatt, a csarnok északi végében nyíló ablak két oldalán Luther Márton és Melanchton Fülöp képét tartotta számon a könyvtáros. A nagyteremben tehát összesen tizennégy portrét írt le. A terem előterében Kelemen nyolc további képet

${ }^{17}$ Bővebben: OrBán János, Bécstöl Székelyudvarhelyig. Támpontok Ugrai László munkásságának valós értékeléséhez = Fundálók, pallérok, épitészek Erdélyben, szerk. Orbán János, Marosvásárhely, Kolozsvár, Maros Megyei Múzeum, Erdélyi Múzeum-Egyesület, 2016, 91-157.

18 A fejezet alapjául egy 2013-ban megjelent bővebb tanulmány szolgált: OrBÁN János, Portrék a könyvek között = Ars Hungarica, 39(2013), Supplementum, Tanulmányok Kelényi György tiszteletére, 172-180.

19 Közli: Clauser Mihály, Nagy-Ernyei Kelemen Márton leírása a Teleki-tékáról = TELEKI Domokos, Clauser Mihály, Varjas Béla, Gróf Teleki Sámuel-emlékünnep, Budapest, Királyi Magyar Egyetemi Nyomda, 1940, 9-14. 
vett számba: itt a fehér zászlót tartó Attila király után Wesselényi Ferenc magyarországi palatinus, Teleki László, Apafi Mihály fejdelem, Lázár János költő és erdélyi államférfi, Wesselényi Kata, valamint szülei, báró Wesselényi Ferenc és felesége, Rhédey Zsuzsanna arcmása sorakozott a falakon.

Kelemen leírása a jelek szerint Kazinczy Ferenc kérésére készült, aki 1816ban meglátogatta az intézményt, és az élményeit megörökítő Erdélyi levelek szövegváltozatait nagy gonddal tökéletesítette a későbbiekben. A Tékára vonatkozó $V$. levél szövegét 1816-1831 között többször frissítette, ${ }^{20}$ a pontos információk beszerzése érdekében terjedelmes levelezésekbe bocsátkozott a helyszínt jól ismerő személyekkel. ${ }^{21} 1817$ novemberében Döbrentei Gábor is ezért készített számára leírást a Téka portréiról. Ez szinte mindenben egybevág Kelemen Márton 9 évvel későbbi jegyzékével, bizonyítva, hogy a portrék már ekkor a későbbi rend szerint sorakoztak a termekben. ${ }^{22}$ Kazinczy nyilatkozott először a gyüjtemény értékéről a mükritikus szemével, sőt, az erdélyi kiválóságok arcképcsarnokává való továbbfejlesztésének ötletét is felvetette. ${ }^{23}$

Származásukat tekintve a könyvtárterem és az elötér portréanyagában a levéltári kutatások alapján három fő csoportot különíthetünk el. Az első a korábban is a kancellár tulajdonában lévő képeké, ezek közé tartozik a sáromberki kastély leltáraiban korábban felbukkanó Savoyai Jenő és Apafi Mihály arcképe. Bethlen Gábor és Teleki Mihály, valamint a kancellár és felesége egy-egy portréját Nagyváradról szállították Sáromberkére, majd 1796 táján vitték Marosvásárhelyre. A második csoportot a Wesselényi Katától a Teleki Téka későbbi otthonául szolgáló marosvásárhelyi házzal együtt örökölt gyüjtemény képezi, ez az előtérben elhelyezett, föként családi vonatkozású képeket tartalmazó együttes magva (Wesselényi Ferenc palatinus, Wesselényi Ferenc és felesége Rhédey Zsuzsanna, Rhédey Zsigmondné, valamint Lázár János portréja). ${ }^{24}$ A harmadik, legjelentősebb csoportba a kifejezetten a terem számára rendelt festményeket soroljuk. Teleki 1802-ben levélben kérte fel Széchényi Ferencet és Festetics Györgyöt arcmásuk elkészíttetésére, hogy az a könyvtárban ,azon jeles személyeknek,

${ }^{20}$ A megjelent szövegváltozatok a következők: a Kaziczy által 1817 februárjában Telekihez pontosítás végett elküldött kézirat (Közli: DeÉ NAGY 1976, i. m. 189-195), a Tudományos Gyüjteményben megjelent 1817-es (KAZINCZY 1817, i. m. 3-8), az Abafi Lajos által közzétett 1824-es (KAZINCZY Ferenc, Erdélyi levelek, szerk. Abafi Lajos, Budapest, 1880, 102-111), a Toldi Ferenc által 1839-ben kiadott 1827-es (KAZINCZY 1839, i. m. 202-207), valamint a Felsömagyarországi Minervában napvilágot látott 1831-es (Kazinczy Ferenc, Erdélyi levelek III. = Felső Magyar-Országi Minerva, 7(1831), 570-576) változat. Abafi 1880-as kritikai kiadása a többi változatra is tekintettel van.

${ }^{21}$ Kazinczy Ferencz levelezése, XV. kötet, szerk. Váczy János, Budapest, Magyar Tudományos Akadémia, 1905, 62, 364, 418, 469, 577.

${ }^{22}$ Döbrentei Gábor Kazinczy Ferenchez. Marosvásárhely, 1817. november 29. Közli: VÁczY 1905, i. m. 364.

${ }^{23}$ KAZINCZY 1839, i. m. 204.

${ }^{24}$ A gyüjtemény kialakulásának további részletei: OrBÁN 2013, i. m. 173-175. 
kik a' Haza késő maradéka ditső emlékezetére is érdemesek, sorában függjön.”25 1803-ban szerezte meg Brukenthal Sámuel Franz Anton Bergmann által 1776ban festett portréját. ${ }^{26}$ Mátyás király arcképét 1805 -ben másoltatta a strassburgi Schöpflin-könyvtárban őrzött eredetiröl, Jeremias Jakob Oberlin közbenjárásával. ${ }^{27}$ A 18. században hiteles Mátyás-portrénak tartott, ún. bécsújhelyi típusú arckép ${ }^{28}$ másolatát Strassburgban Gottfried Christian Enslen (1757-1818) készítette, ${ }^{29}$ ez a Tékában fennmaradt két Mátyás-portré közül vélhetően a jobb minőségüvel azonos. A nagyterem számára festette Johann Tusch a kancellárt a Szent István-rend nagykereszteseinek díszöltözetében megjelenítő, egész alakos portrét is 1808 táján.

Felmerül a kérdés, hogy az eltérő eredetü képekből mikor válogatták össze a Döbrentei és Kelemen leírásából körvonalazódó gyüjteményt. A jelek szerint elhúzódó folyamatról van szó, mely a könyvtárnyitás (1802) után kezdődött, és valamikor az 1810-es évek derekán teljesedett ki. Molnár Ádám asztalos 1808 táján végzett munkái között bukkan fel tételként a kancellár, Teleki József, Luther és Melanchton portréinak rámázása, valamint a „Thécabeli képek felrakása” - a berendezés egyik hulláma tehát ekkoriban zajlott, bizonyára az egészalakos portré felhelyezésével egyszerre. Az 1815 nyarán a Bécsben élő Teleki Sámuel és fia, Ferenc között zajló levélváltás azt sejteti, hogy ez idő tájt újabb, a portrékat is érintő átrendezés zajlott a könyvtárban. Később, Kazinczy látogatása után függeszthették ki Festetics, Széchényi és Mátyás király portréját; Döbrentei 1817-es beszámolójában a gyüjtemény (a később az előtérben felbukkanó Attila királyt leszámítva) már a Kelemen Márton által rögzített végleges állapotában volt. ${ }^{30}$

A portrék egy helyre kerülésében, mint láttuk, elég nagy szerepet játszott a véletlen. Későbbi csoportosításuk azonban már korántsem tủnik esetlegesnek. A nagyteremben elhelyezett galéria koncepcióját a Széchényi Ferenc (17541820) és a Festetics György (1755-1819) portré rendelésének tudatossága sejteti: mindketten a Telekiéhez hasonló, közhasznú könyvtáralapítási törekvések emblematikus képviselői voltak Magyarországon. Nem tekinthető véletlennek a gyulafehérvári Batthyaneum könyvtárát megteremtő Batthyány Ignác (1741-1798) erdélyi püspök, valamint a további fontos erdélyi könyvgyüjteményeket létrehozó Brukenthal Sámuel (1721-1803) gubernátor és Teleki József

${ }^{25}$ Gulyás Károly, Benkő József, gr. Széchenyi Ferencz, gr. Festetich György, Aranka György levelei gr. Teleki Sámuelhez = Irodalomtörténeti Közlemények, 20(1910), 214-223.

26 Teleki Sámuel Szász Józsefhez. Bécs, 1803. július 26. Közli: DeÉ NAGy 1976, i. m. 120-121. A szignó a vászon hátlapján olvasható: „,Frantz Anton bergm[ann] / Cibinio pinxit / 1776. ”

${ }^{27}$ F. CsanaK Dóra, Hogyan vásárolta meg Teleki Sámuel a Tacitus-corvinát? = Emlékkönyv Jakó Zsigmond születésének nyolcvanadik évfordulójára, szerk. Sipos Gábor, Kolozsvár, Erdélyi Múzeum-Egyesület, 1996, 99-106.

28 SzENTESI Edit, Mátyás király bécsújhelyi típusú arcképeiről = Hunyadi Mátyás, a király. Hagyomány és megújulás a királyi udvarban 1458-1490, szerk. Farbaky Péter et alii, Budapest, Budapesti Történeti Múzeum, 2008, 217-219.

${ }^{29}$ A festő azonosítására vonatkozóan lásd OrBán 2013, 22. lábjegyzet.

30 Orbán 2013, i. m. 175. 
(1738-1796) koronaőr portréjának beszerzése sem. A Bibliotheca Corvinianát alapító Hunyadi Mátyás (1443-1490) magyar király, valamint Bethlen Gábor (1580-1629) erdélyi fejedelem történelmi távlatban kifejtett könyvgyüjtő tevékenysége révén kerülhetett be a válogatásba: a Magyar Athénás című művét 1766-ban Teleki Sámuelnek (is) dedikáló Bod Péter erdélyi tudós ajánlásában kiemelten méltatta a két uralkodó könyvszeretetét; katalógusa első kötetének bevezetőjében maga Teleki is ezt hangsúlyozta róluk. ${ }^{31}$ Minden bizonnyal Savoyai Jenő sem hadvezérként vívta ki az alapító tiszteletét: útinaplójából tudjuk, hogy a herceg bécsi császári könyvtárban őrzött gyüjteménye 1759-ben egyik legkorábbi nyugat-európai könyvtár-élménye volt. ${ }^{32}$ Bethlen Zsuzsanna jelentős magyar könyvtára, a legnagyobb 18 . századi erdélyi női könyvgyüjtemény megteremtőjeként érdemelhette ki helyét férje oldalán a galériában. ${ }^{33} \mathrm{Az}$ ábrázoltak tehát tekintélyes könyvgyüjtemények létrehozói - az arcképek együttesen állítanak emléket a könyvek iránti tiszteletnek és a felvilágosodás tudásba vetett hitének, a mögöttes jelentést pedig maga a „kiállítótér” hordozza. Az egyetlen ősgalériába kívánkozó kivétel a család felemelkedését megalapozó Teleki Mihály (1634-1690) portréja; Luther és Melanchton szereplését Teleki elkötelezett protestáns volta magyarázza, utóbbi kettő azonban sem elhelyezését, sem méretét tekintve nem képezte részét vizuálisan a központi csarnok gyürüjében a pillérekre függesztett együttesnek. A nagyterem szük elöterében elhelyezett nyolc portré összeválogatásában már kevésbé érvényesült tervszerüség - nagyrészt a marosvásárhelyi házzal együtt Wesselényi Katától örökölt, az ő otthonában kialakult gyüjtemény darabjai kerültek ide.

A forrásokban a fentiek ellenére nincs egyértelmü utalás arra, hogy Teleki szeme előtt egyfajta könyvtáralapítók arcképcsarnokának létrehozása lebegett volna. Az idevágó kevés írott forrás inkább a közérdek szolgálatát említi a portrégaléria tagjainak közös vonásaként. Kiemeli ezt Teleki Sámuel Széchényivel és Festeticcsel való levélváltása a portrék megrendelésekor, de így élt ez a kortársak tudatában is: Kelemen Márton megfogalmazásában a teremben olyan emberek képei láthatók, akik „Erdély Országban, vagy pedig Magyar Országban a’ köz haszonra valamit fundáltak"; "tudományok pártfogása által megszentelt nevek" - vélekedett róluk Kazinczy. ${ }^{35}$

A portrégyüjtemény történetének ismeretében a Teleki Téka esetében nem beszélhetünk esztétikai indíttatású, szervezett mügyüjtésről, a kancellárt elsősorban a terem ékesítésének szándéka vezérelte. Közelebbi-távolabbi párhuzamokban nem szükölködik a magyar mủvészettörténet, de a kortárs könyvtárakban a Te-

${ }^{31}$ BuzÁsI Enikő, A barátság-motívum térhóditása a 18. századi magyar portréfestésben = Müvészettörténeti Értesitö, 33(1984), 232.

${ }^{32}$ Gróf Teleki Sámuel erdélyi kancellár úti naplója 1759-1763, s. a. r. Biás István, a bevezetést írta dr. IMre Sándor, Marosvásárhely, nyomatott a „Kossuth” Nyomdában, 1908, 8.

33 Dé́ Nagy 1997, i. m. 202-207.

34 Clauser 1940, i. m. 13.

35 Kazinczy 1839, i. m. 203. 
leki Téka könyvgyüjtőitől eltérően inkább a tudósportrék jellemzőek. Széchényi Ferenc a Téka megnyitásával egy időben, 1802-ben ajánlotta fel könyvtárát Magyarországon a nemzet számára, könyvei 1803-ban az egykori pesti pálos kolostor könyvtártermében nyertek elhelyezést. Ez év tavaszán készíttette el a milánói Pietro Rivettivel a terem mennyezetfestményét, melynek közepére a két angyal által tartott magyar címer, peremére a magyar országrészeket jelképező címerek és a különféle tudományágak szimbólumai kerültek. Körben, a szekrénysorok felett azonban 30 festett medalionban magyar tudósok arcképei kaptak volna helyet, többségükben a közelmúlt, a 18. század személyiségei. A portrék ugyan nem készültek el, az ábrázolni szándékozott személyek kilétét azonban a medalionok feliratai alapján ismerjük. ${ }^{36}$ Széchényi ikonográfiai programja igen jelentős számunkra, mert egy, a Teleki Sámueléhez mindenben hasonló (azonos indíttatású, azonos közegből eredő) egykorú kezdeményezés képzőművészeti keretét adta volna. Hasonló portrék a 18. századi egyházi könyvtárak termeiben is gyakran előfordultak: Patachich Ádám kalocsai könyvtárának polcai felett antik és kortárs szerzőket festett meg Maulbertsch, ${ }^{37}$ az egri Lyceum könyvtárának 24 fa relief büsztje között evangélisták és szentek társaságában szintén találunk tudósokat (közöttük három magyar, Werbőczy, Pázmány és Istvánfi Miklós is feltünik). ${ }^{38}$ A gyulafehérvári Batthyaneum csillagvizsgálójának asztronómusokat megjelenítö ikonográfiai programja is ebbe a vonulatba kapcsolható. ${ }^{39}$

Teleki Sámuel és Széchényi Ferenc „válogatását” eltérő koncepciójuk ellenére összeköti két újszerünek tekinthető vonás: hangsúlyosan hazai, magyar jellegük, valamint a jelen és a múlt kiválóságainak együttes megjelenítése. Teleki könyvtárában a távolabbi múltat a szellemi ősökre való utalásként Bethlen Gábor és Mátyás király idézi, de gyüjteményébe zömmel kortárs szellemi rokonait emelte be. Hasonló jelenség figyelhető meg korábban a Telekiekkel rokonságban álló Ráday Gedeon (1713-1792) péceli képtárában is: a magyar tudósok arcképcsarnokának szánt (Icones eruditorum Hungarorum), de a magyar kiválóságok gyüjteményévé terebélyesedett kollekció Szent Istvántól a 18. századig terjedt, a kortársak azonban megkülönböztetett figyelemnek örvendtek benne. ${ }^{40}$ Később,

${ }^{36}$ Farbaky Péter, Pálos könyvtár vagy nemzeti könyvtár? = A Magyar Nemzeti Galéria Évkönyve 1991, Bp., 237-247.

37 JeRnyey Kiss János, Patachich Ádám és a kalocsai érseki rezidencia = Patachich Ádám érsek emléke, szerk. Lakatos Adél, Kalocsa, 2005 (A Kalocsai Főegyházmegyei Gyüjtemények kiadványai, 4), 67-70.

38 Vort Pál, Heves megye müemlékei, II. kötet, Budapest, Akadémiai, 1972, 468-469; Jávor Anna, A tridenti zsinat. Johann Luckas Kracker és Joseph Zach freskója az Egri Liceumban = Müvészettörténeti Értesitö, 42(1993), 160.

${ }^{39}$ Kovács András, Program és müalkotás a 18. század végi Erdélyben. A gyulafehérvári Batthyaneum csillagvizsgálója = Stílusok, müvek, mesterek. Erdély müvészete 1690-1848 között, Tanulmányok B. Nagy Margit emlékére, szerk. Orbán János, Marosvásárhely, Kolozsvár, Erdélyi Múzeum-Egyesület, Maros Megyei Múzeum, 2011, 118-136.

40 Koós Judith, Ráday Gedeon könyv-és mügyüjteménye a 18. században. Aszód, Petőfi Múzeum, 1994, 132-144. 
az 1820-as évek végén készült el a pannonhalmi bencés apátság nagy könyvtártermének ikonográfiai programja, a bécsi Josef Klieber a mennyezet két hosszanti oldala mentén medalionokban itt is hazai kiválóságok portréit festette meg, ${ }^{41}$ a közelmúlt tudósait is beemelve a programba.

Összegzésként megállapítható, hogy a nagyteremben elhelyezett portrégyüjtemény több vonatkozásban is jól beleilleszthető a magyar könyvtár-ikonográfiai hagyományba: amikor az alapító a tulajdonában lévő, örökölt vagy épp a könyvtár számára szerzett festményekből összeválogatta szellemi rokonainak panteonját, Ráday Gedeonhoz vagy Széchényi Ferenchez hasonlóan hazai (erdélyi vagy magyarországi) kiválóságok, ezen belül is a kortársak megjelenítését tartotta fontosnak. Sajátos vonás, hogy többségük könyvtáralapítási törekvései révén érdemelhette ki helyét a galériában - nehéz ugyanis a tudatosság hiányát feltételeznünk amögött, hogy csaknem mindannyian szoros kapcsolatban álltak a könyves kultúrával, a társaságban pedig teljes létszámban helyet kaptak a Telekiéhez hasonló kortárs erdélyi és magyarországi könyvtáralapítási törekvések képviselői. A csarnokot a kancellár nagyméretü, egészalakos portréja uralta, a közművelődés előmozdítása érdekében anyagi erőforrásai maximális mozgósítására hajlandó felvilágosult foúr kulcsszerepét hangsúlyozva az alapítás folyamatában.

A portrégyüjtemény egységes jellege és szoros kapcsolata a könyvtárral az intézményt kezelő utódokban úgy tủnik, nem tudatosult: a 19. század derekára a termet családi portrékkal zsúfolták tele (2. kép). Rövidesen elkezdődött a festmények szétszóródása is: a II. világháború előtti években Biró József művészettörténész kiváló minőségü Széchényi Ferenc-portrét látott a sáromberki kastélyban, ugyanitt készült fotón azonosítható egy, a századelőn még a Tékában lévő Bethlen Zsuzsanna arckép, mindkettő a portrégaléria darabjai közül sodródhatott az alapító utódainak kastélyába, ${ }^{42}$ mint ahogy bizonyosan a Tékából vándorolt ide az egyik, a kastély kártyaszobájában megörökített férfiportré is. ${ }^{43} \mathrm{~A}$ második világháború előestéjén a családi portrék már nincsenek a teremben, a kancellár egész alakos portréja mellé Mária Terézia és II. József portréja került (3. kép). A gyüjtemény szétszóródása a kommunizmus évtizedeiben folytatódott. A 21. század elején a Teleki Téka a hajdan a nagyteremben található gyüjteményből tíz festményt őriz: Teleki Sámuel egészalakos és Johann Michael Millitz által 1766-ban, Bécsben festett fiatalkori portréját (1. kép), Teleki Mihály, Bethlen Gábor, Mátyás király, Brukenthal Sámuel, Teleki József ${ }^{44}$ és Batthyány Ignác arcmását. A közelmúltban

${ }^{41}$ Sisa József, A Könyvtár és a torony épitése = Mons Sacer 996-1996, Pannonhalma ezer éve, II. kötet, szerk. Takács Imre, Pannonhalma, 1996, 148.

${ }^{42}$ BIRÓ József, Erdélyi kastélyok, Budapest, Új Idők Irodalmi Intézet, é. n. [1943], 97-98. LI. tábla

${ }^{43}$ Uo. XLVIII. tábla. Baloldalt, az ajtó mellett, barokkos rámában.

${ }^{44}$ A festményt 2014-ben restaurálták az Imago Picta műhely munkatársai. A 20. században, kikerülve a könyvtárból, sokáig a palota emeleti nagytermétől északnyugatra lévő raktár bejárata fölött függött, jelen sorok szerzője legalábbis ott látta elöször a 2000-es évek elején. Biró József, majd Csanak Dóra így említhette 'eredeti helyéről elkerült' képként. Csanak reprodukciót is közölt 


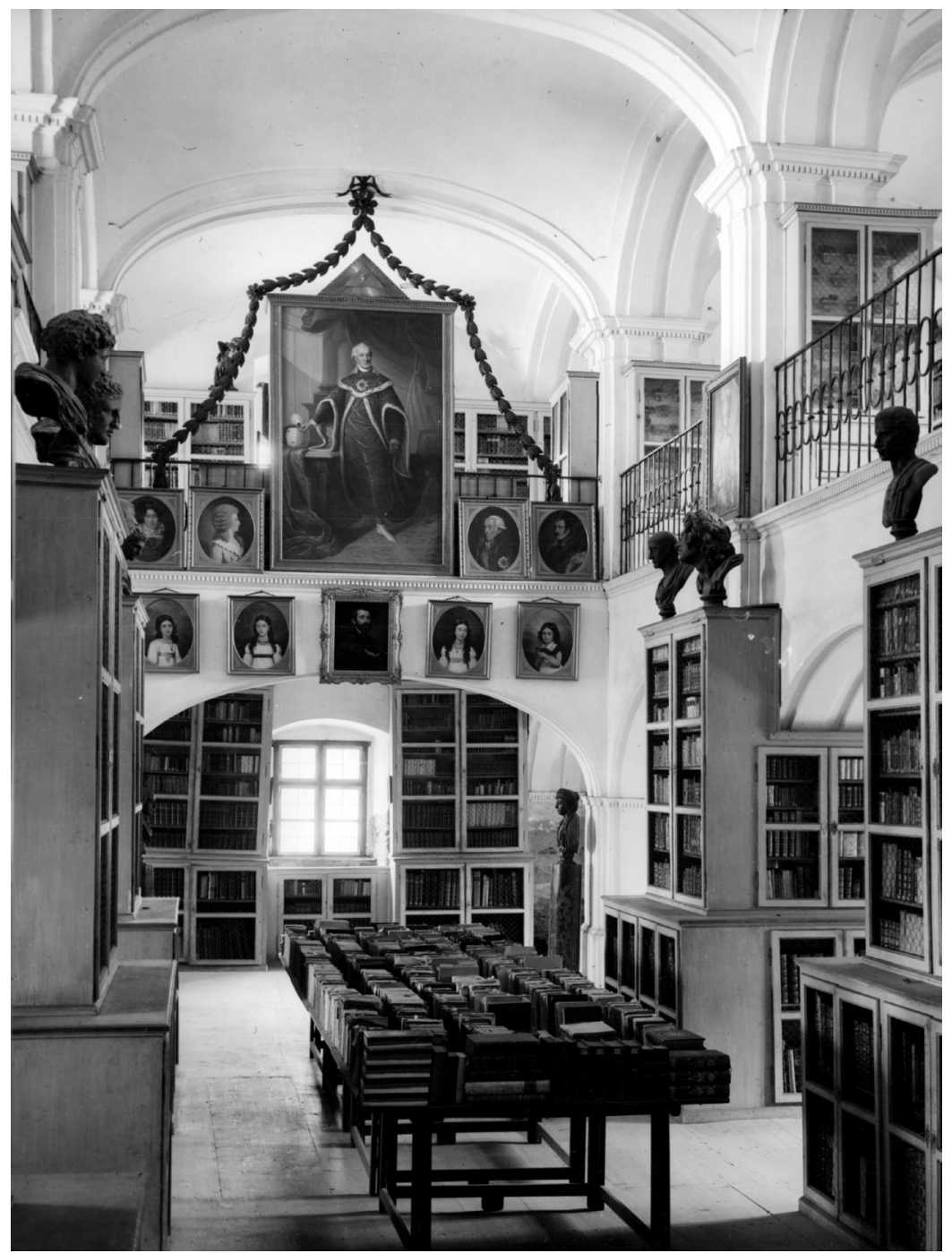

2. kép

A könyvtárterem a 20. század elején. Haranghy György felvétele (Magyar Néprajzi Múzeum Fotótára, Budapest, nr. 19766)

szerencsés módon elökerült a gyüjteményből Luther Márton és Melanchton Fülöp jóval kisebb méretủ, vászonra festett portréja is.$^{45}$ Mindezek mellett a nagyterem

róla, rámutatva múvészi kvalitásaira. Vö. CsanaK Dóra, Két korszak határán. Teleki József, a hagyományörzö és a felvilágosult gondolkodó, Budapest, Akadémiai, 1983, 4, 431. (81 lbj.)

${ }^{45}$ Méreteik azonosak: $27,5 \times 21,5 \mathrm{~cm}$. 
őrzi még a Mátyás-portré ismeretlen körülmények között keletkezett másolatát, valamint egy idősödő foúr portréját a 18 . század második feléből. ${ }^{46}$

Végezetül megjegyezzük, hogy egy 1842-es leltár szerint a nagyterem bejárata melletti „kis Kabinétba” az alapító idejéből maradt metszetek, rajzok, címerek között számos metszetportrét is tároltak. ${ }^{47} \mathrm{~A}$ jól ismert családi portrék és mások mellett Bethlen Gábor, Izdenczy József, Gvadányi József, Gyöngyösi János, Cserei Farkas, vagy épp Kant, Gutenberg arcmása tünik fel. Számos metszetet Czetter Sámuel, vagy a kancellár erdélyi pártfogoltjai, Nagy Sámuel és Falka Sámuel készítettek a századforduló táján Bécsben. De itt őrizték a Kazinczy által ajándékozott, Baróti Szabó Dávidot ábrázoló olajfestményt is, ${ }^{48}$ valamint egy fekete krétarajzot Mátyás királyról.

\section{Szobrok}

A terem fenséges hangulatát a könyvszekrények tetejére helyezett, patinázott gipszszobrok fokozzák. A zömmel antik ihletettségü 63 szobor szintén Bécsből érkezett, a kancellár 1802 végén kelt, saját kezü megrendelőlistája a napjainkra hiányos együttes eredeti összetételének becses forrása ${ }^{49} \mathrm{Ez}$ a vásárlási jegyzék „Buste” (mellszobrok) és „Figuren” (alakos ábrázolások) címek alá rendezett csoportokban sorolja fel a szobrokat. Mivel utóbbiak meglátásunk szerint tematikus és formai egységeket képeznek, alább ezt a csoportosítást követve mutatjuk be a Teleki által igényelt alkotásokat. Az első 20 mellszobor csoportja antik szerzőket, tudósokat, filozófusokat - Homérosz, Szolón, Szapphó, Anakreón, Thalész, Püthagorasz,

${ }^{46}$ Bár egyértelmủ bizonyíték még nincs erre, életkora és a datálás alapján meglehet, hogy Teleki László Kelemen által számbavett portréjával azonos. Erre utalhat az a Nemes Károly könyvtáros által vélhetően az 1940-es években felvett jegyzék, mely Teleki László portréját 'meglévőként' jelzi. Lásd Jegyzék a Teleki Téka portréiról, Datálatlan, Erdélyi Református Egyházkerület Kolozsvári Gyűjtőlevéltára, Bustya Endre hagyaték, Teleki Téka mappa. A forrást Bányai Réka könyvtáros bocsátotta a rendelkezésünkre, amit ezúton köszönünk.

${ }^{47}$ Consignatioja azon Képeknek, Tabelláknak, Czímereknek és más Rajzalataknak, melyek a nagy Pappendeckelbe vagynak sub Lit. B. 1842. Teleki személyi levéltár, Teleki-Bolyai Könyvtár, sz. n.

${ }^{48}$ Az erdélyi nagyságok arcképcsarnokának létrehozására buzdító, fellelkesült Kazinczy már 1817-ben jelzi, hogy a Tékába szeretné küldeni Baróti Szabó Dávid Klimesch Tamás által 1788ban Kassán festett portréját; az Erdélyi levelek későbbi kiadásaiban már mint megtörtént tényről tesz erről említést. A kép meg is érkezett Marosvásárhelyre, emellett tanúskodik a Kazinczy által a könyvtárnak küldött könyvek jegyzéke („Szabó Dávid Mejképe le-festve 1788. Julius 24-kén, festette Kazinczy Ferenc”, vö. DeÉ NAGY 2002, i. m. 150), a fenti adat szerint azonban nem helyezték ki a teremben. Orbán Balázs még látta, ma már nem található a könyvtárban.

${ }^{49}$ A rendelés előlegét 1802. december 8-án fizette ki Teleki. A jegyzék lelöhelye: Magyar Nemzeti Levéltár Országos Levéltára, Teleki család marosvásárhelyi levéltára, Teleki Sámuel osztály, P 661 [a továbbiakban MNL OL, P 661], 24. cs. 1803, f. 405-406. Az értékes forrást Deé Nagy Anikó azonosította: Dé́ NaGY 1997, i. m. 224. 
Hérakleitosz, Hippokratész, Euripidész, Démokritosz, Szókratész, Platón, Zénón, Epikurosz, Démoszthenész, Diogenész, Cato, Cicero, Seneca és írói munkásságára való tekintettel Marcus Aurelius - vonultat fel. A második büszt csoportba a görögrómai történelem 18 jeles személyisége - Akhilleusz, Nagy Sándor, Hektor, Brutus (?), Scipio Africanus, Brutus, Pompeius, Julius Caesar, Antonius, Maecenas, Augustus, Tiberius, Nero, Vespasianus, Titus, Traianus, Hadrianus, Antoninus Pius - került. A harmadikban Habsburg császárok - Mária Terézia, II. József, II. Lipót és II. Ferenc - jelennek meg, ám itt eredetileg „Carl” (vélhetően Károly főherceg, Mária Terézia fia), Ernst Gideon von Laudon és Frantz Moritz von Lacy ${ }^{50}$ hadvezérek, Wenzel Anton Kaunitz kancellár, sőt, egy, a Habsburg Birodalom nagyjaitól biztonságosan elkülönített ,alcsoportban” II. Frigyes császár és Bonaparte Napóleon is szerepelt. Utóbbi hatot azonban a kancellár végül kihúzta - helyüket a szigorú aulikus szellem jegyében Mária Terézia és II. Lipót vette át, ezáltal a kortársak száma a Teleki által szolgált négy császárra zsugorodott. A következő csoport már a görög-római mitológia alakjaié: Jupiter, Apolló, Pallasz-Athéné, Venus és Mercurius neve mellett B betü utal arra, hogy büsztökröl, Saturnus és Rhea esetében pedig F arra, hogy figurális ábrázolásokról van szó. A „Figuren” címmel illetett utolsó két csoport közül az elsőről - Minerva, Apolló, Venus Coelestis, Venus Medic[i], Mercurius, Léda, Bacchus, Hercules, Flora, Faunus - a ma meglévő darabok alapján úgy véljük, hogy az egyalakos ábrázolásokat tartalmazta, míg a második - Apolló és Daphne, Neptunus, Hercules és Antaeus, A szabin nők elrablása - a többalakos kompozíciókat.

A kancellár tehát összesen 47 büsztöt és 16 alakos ábrázolást vásárolt. A császárvárosban olcsón beszerezhető sokszorosított gipszmásolatok a könyvtár ékesítésének költséghatékony módját kínálták: a 63 szobor kétoldalas listájának végére feljegyzett kalkulus szerint egységáruk mérettől függetlenül mindössze 8 rajnai forint volt, összegük ismeretlen jogcímen 31 és fél rajnai forinttal egészült ki, így a vétel összértéke 535 rajnai forint 30 krajcárra rúgott. Összehasonlításképp megjegyezzük, hogy Franz Thaller két darab bronzszobra ugyanekkor szinte háromszor ennyibe, 1500 rajnai forintba került. A summát 1802. december 8. és 1803. július 9. között tíz részletben hiánytalanul ki is fizette Teleki. Átvételét egy bizonyos Mathias Mayer ellenjegyezte - pontos szerepe egyelöre nem tisztázott: a forrás csak eladói mivoltára enged következtetni, arról nem vall, hogy a gipszmunkák alkotójáról vagy szobrászról lenne szó. ${ }^{51}$

${ }^{50}$ Az áthúzott névből csak a „Laci” szó betűzhető ki, a tematikus összefüggés alapján a hadvezérre következtethetünk.

${ }^{51}$ Mathias Mayer neve nem ismerős a századforduló osztrák müvészetének történetében. Bécs városának 1803-as címjegyzéke sem tartja nyilván a szobrászok között, említ viszont egy ilyen nevü lakost Jägerzeil városrészben, a Praterstrasse 18. sz. alatt, a „grüne Baum” cégtábla tulajdonosaként. Vollständiges Auskunftsbuch, oder einzig richtiger Wegweiser in der k. k. Haupt- und Residenzstadt Wien ... auf das Jahr 1803. Verlegt bey Joseph Gerold..., 61-62, 158-159. Nehézkes aláírása sem jelzi „Bildhauer” minőségét. Személyére az értékes forrást először azonosító Deé Nagy Anikó utalt futólag szobrászként (DeÉ NAGY 1997, i. m. 224), ezt vette át a későbbi iroda- 
A szobrok 1803 júliusában már készen álltak a szállításra, ${ }^{52}$ azt azonban nem tudjuk, hogy a törékeny portéka megérkezett-e hiánytalanul a Maros-parti városba. A kommunista államosítás idején, 1949-ben mindenesetre már csak 47 gipszszobrot vettek számba az egykor vásárolt 63-ból..$^{53}$ Ám komolyan mérlegelnünk kell annak lehetőségét is, hogy eredetileg sem mind a nagyterembe kerültek a „férőhelyek” száma a ma meglévő szekrényeken is nehezen tenné lehetővé 63 szobor elhelyezését, arról nem beszélve, hogy a polcok java része 1803-ban még egyáltalán nem állt készen. A 20. század közepén meglévő 47 szobor mindenesetre hiánytalanul megérte az ezredfordulót. Ekkor ébredt fel a gyűjtemény iránti művészettörténeti érdeklődés is: 2002-ben Kimpián Annamária vette számba őket, tisztázva jelentős részük feledésbe merült identitását. ${ }^{54}$

Az idők folyamán megváltozott rend szükségessé teszi a szobrok eredeti elhelyezésének vizsgálatát is. Némi támpontot a gipszeket sajnos csak futólag említő Kelemen Márton 1826-os leírása és a 20. század első feléből származó archív fotók nyújtanak. A földszint szekrényein Kelemen császárportrékat említ: „az oszlopok körül lévő Thékák tetején római császárok képeik vagynak egész kereken" ${ }^{55}$ (Ez alatt általánosságban vezetőket, államférfiakat kell értenünk, hiszen már a megrendelőlistán kisebb volt a valódi császárok, mint a földszinti szekrényeken elhelyezhető szobrok száma.) Az 1940-es évek elején még a szekrények párkányzatára rögzített - mára elkallódott - feliratos táblácskák tájékoztattak az ábrázoltak kilétéről. Feltételezzük, hogy ezek némileg a szobrok mozgatását is korlátozták, így a 20. század első felének archív fotói bizonyos mértékben mérvadóak az eredeti rendet illetően (2-3. kép). Annál is inkább, mert a földszinti polcokról még mindig zömmel a császárportréknak vélt büsztök tekintettek le a látogatóra: belépve balra az első szekrényen a feliratos táblákon Marcus Aurelius és Vespasianus, jobbra az elsőn Traianus és Titus, a másodikon Augustus és Tiberius neve betüzhető ki, a harmadikon az ún. haldokló Nagy Sándor jellegzetes alakja ismerhető fel, mellette Scipio Africanus körvonalai sejthetőek.

A szobrok többsége az emelet polcain kapott helyet. A szükszavú Kelemen szerint itt „görög és római classicus emberek fejeiket gipsből feketén bronzirozva” helyezték el. ${ }^{56} \mathrm{Az} 1940$ utáni felvételeken a galérián, a kerti oldal polcain ifjabb Cato és Cicero tünik fel, itt azonosítható a korban Seneca-portréként is forgal-

lom: KIMPIÁN Annamária, A Teleki Tékát díszitő szobrok= Emlékkönyv a Teleki Téka alapításának 200. évfordulójára 1802-2002, szerk. Deé Nagy Anikó, Sebestyén Spielmann Mihály, Vakarcs Szilárd, Marosvásárhely, Mentor, 303.

52 Teleki Sámuel Szász Józsefhez. Bécs, 1803. július 26. Közli DeÉ Nagy 1997, i. m. 345.

53 DeÉ Nagy Anikó, A marosvásárhelyi Teleki Téka a második világháború után = Emlékkönyv a Teleki Téka alapitásának 200. évfordulójára 1802-2002, szerk. Deé Nagy Anikó, Sebestyén Spielmann Mihály, Vakarcs Szilárd, Marosvásárhely, Mentor, 182.

${ }^{54}$ Kimpián 2002, i. m. 302-313. Azóta a 2011-es felújítás idején sajnos elpusztult az általunk Perszeuszként azonosított alkotás is.

${ }^{55}$ Clauser 1940, i. m. 13-14.

${ }^{56}$ Clauser 1940, i. m. 13-14. 


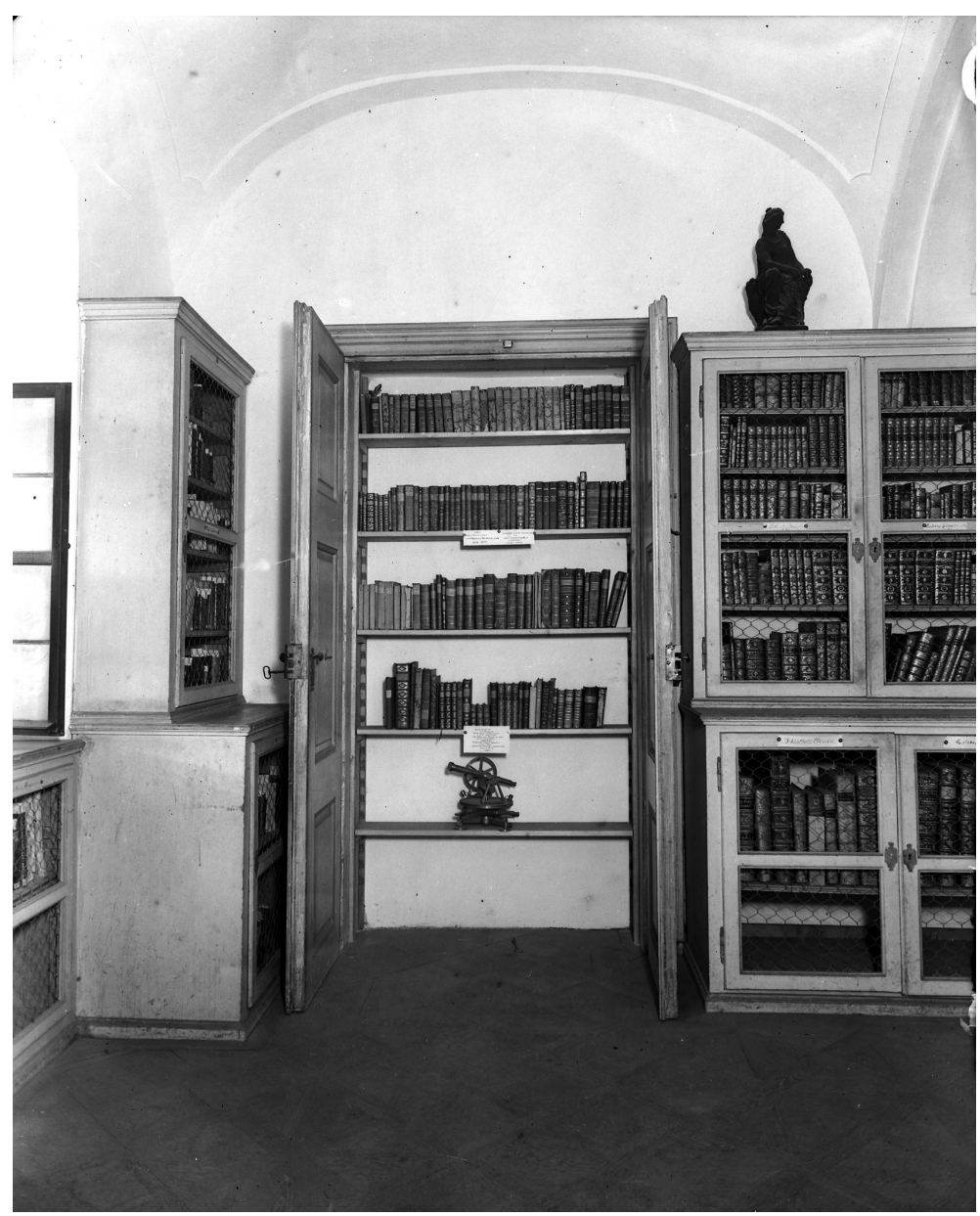

3. kép

A könyvtárterem 1940-1944 között

(Az egykori Kulturális Örökségvédelmi Hivatal Fotótára, Budapest, nr. 17310)

mazott, ${ }^{57}$ égre tekintő idős férfit ábrázoló büszt is. Átellenben, az udvari oldalon Hermész archaikus stílusú portréjának jellegzetes, szakállas kontúrja sejlik fel, ez bizonyára a megrendelölista Mercurius-büsztjével lesz azonos. ${ }^{58} \mathrm{~A}$ könyveket illetően szintén Kelementől tudjuk, hogy a két emeleti bejárat közötti rövidebb oldalon a görög klasszikusokat, az udvar felöli hosszanti oldalon a római szerzők és az egyházatyák műveit, átellenben, a kert felől a magyar történeti irodalmat,

${ }^{57}$ Cristiano Giometri, Sculture in terracotta. Museo Nazionale del Palazzo di Venezia, Roma, Gangemi Editore, 2011, 38.

${ }^{58}$ Kimpí́n 2002, i. m. 313. Cat. 43. 
valamint Bethlen Zsuzsanna magyar könyveit tárolták. ${ }^{59} \mathrm{~A}$ vázolt 20. század eleji állapot tehát egyelőre nemigen enged a szobrok eredeti elhelyezése és a könyvek helyrajzi rendje közötti programszerü összefüggésre következtetni.

A terem ékességei közül talán ezek a komor tekintetü büsztök idézik leghívebben a könyvtáralapító „latin gróf” szellemi arcélét: fiatalkorától az antik szerzők voltak legkedvesebb olvasmányai, müveik gyüjteményének féltett darabjait képezték, legjobb kiadásaikat anyagiakat és fáradtságot nem kímélve kutatta fel és vásárolta meg. ${ }^{60}$ Tudjuk, hogy Bécsben ezeket nem is az ottani könyvtárteremben, hanem saját dolgozószobájában őrizte. ${ }^{61}$ Meggyőződése szerint ők voltak „minden müveltségnek a forrásai”, a könyvtárkatalógus első kötetét teljes egészében nekik szentelte, sőt, életrajzaikkal is kiegészítette. A római császárok, felelős államférfiak példája szintén közelről foglalkoztathatta az Erdély ügyeit bő három évtizedig a legfelsőbb szinten igazgató, a kormányzás felelősségével és gondjaival naponta szembesülő kancellárt. Egyébként az antikvitás kiválóságainak képzőművészeti megjelenítése már a magyar könyvesházakban is létező gyakorlat ekkoriban, elég a hasonló érdeklődésű Patachich Ádám érsek kalocsai könyvtárának Maulbertsch által festett portréira, vagy a pannonhalmi könyvtárterem szegmensíves homlokfalaira festett, antik nagyságokat ábrázoló csoportkompozíciókra gondolnunk. ${ }^{62}$

Oldottabb hangulatot árasztanak a büsztökkel együtt vásárolt mitológiai témájú, figurális ábrázolások. Az általuk megidézett történetek szervesen hozzátartoztak a kor müveltségéhez, ábrázolásaik, mint tudjuk, általánosan elterjedtek a barokk épületszobrászatban és kertművészetben. A kancellár bécsi udvari kapcsolatait tekintve az sem meglepő, hogy a könyvtár fennmaradt tíz mitológiai tárgyú figurális ábrázolása közül többnek a Schönbrunn Johann Wilhelm Beyer (1725-1796) és munkatársai által készített kerti szobrai között fedezhetjük fel az előképét. ${ }^{63}$ Annál is inkább, mivel a szobrok kisméretü (59-68 cm) modelljeit, és máig fennmaradt gipszmásolataikat a 18. század végén ismerték és használták Bécsben, sőt, egy részük még a Képzőmüvészeti Akadémia szobrászati mintatárába is bekerültt. ${ }^{64}$ Nyilvánvaló, hogy Neptunus Tékában őrzött gipszszobra a császári kert pompás Neptunus-kútjának központi jelenetét idézi, melyen Thetisz fia, Akhilleusz tengeri útjának oltalmazását kéri a szigonyos istenségtől. A könyv-

59 Clauser 1940, i. m. 14.

${ }^{60}$ Deé Nagy 1997, i. m. 172.

${ }^{61}$ DeÉ Nagy 1976, i. m. 204.

${ }^{62}$ A pannonhalmi festmények vázlatai szerint az egyik csoportban Cicero, Démoszthenész, Pindarosz, Theokritosz, Aiszkhülosz, Homérosz, Szókratész, Platón, Seneca, a másikban Quintilianus, Arkhimédész, Augustus, Livius, Vergilius, Horatius, Hérodotosz és Hippokratész kapott helyet. SisA 1996, i. m. 211.

${ }^{63}$ Beatrix Hajós, Schönbrunner Statuen 1773-1780. Ein Neues Rom in Wien, Wien, Köln, Weimar, Böhlau Verlag 2004.

${ }^{64}$ Közöttük olyan, a kertben kivitelezetlen alkotások, mint Léda vagy Saturnus, melyek a Teleki által rendelt gipszek azonosításában is segíthetnek a továbbiakban. HAJós 2004, i. m. 50-58. 
tárban található, eddig azonosítatlan női ülőszobor előképe a bécsi kert egyik lugasában meghúzódó Rhea Kübelé alakja ${ }^{65} \mathrm{~A}$ Téka Minervája a schönbrunni 'grand parterre' Minervaként, sisakkal és pajzzsal ábrázolt Aszpáziájával mutat egyértelmủ hasonlóságot. Vele átellenben, a kertben, egy baljában levágott fejet tartó, sisakos férfialak áll: Perszeusz a Medusza fejével. A Tékában azonosítható mása ${ }^{66}$ talán Apollót helyettesíti, hiszen Perszeusz nem szerepel a megrendelölistán. ${ }^{67}$ Úgy tünik, hogy a Tékában jobb kezével a haját kicsavaró, bal kezével a ruháját ágyéka elé vonó Venus analógiái is a kerti szobrok világába vezetnek: kompozíciója Pierre Le Gros versailles-i parkban álló, fürdőből kilépő, ún. Richelieu-Venusához áll közel. A jegyzék Lédájával azonosítható a Téka másik női szobra, mely jobb kezével eredetileg egy hattyú nyakát foghatta (az állat feje mára letörött) ${ }^{68}$ ma a lengyelországi Wilanow kastélyának parkjában található egy hasonló kompozíciójú Léda-ábrázolás.

Több figurális ábrázolás kiemelkedő, már a 18. században nagyra tartott múalkotások másolata: Hercules alakja az egykor a római Palazzo Farnesében (ma már Nápolyban) örzött, Glükón által a Kr. u. 3. században készített népszerü antik másolatot idézi, Bacchus szobra a reneszánsz mủvészet kincsestárából merít, előképe Jacopo Sansovino (1486-1570) Bargellóban őrzött alkotása. A Hadrianus villájában talált, ún. Capitoliumi Antinóosz másolata lesz a Tékában attribútum nélkül megjelenő, meztelen ifjú gipszszobra ${ }^{69}$ - Teleki jegyzékében a nevet ugyan nem találjuk, de minden bizonnyal Hermész (a listán Mercurius) szobraként forgalmazták (ennek tartja a mai kutatás is, de az azonosítás már akkoriban felmerült $\left.{ }^{70}\right)$.

Ha a fenti azonosítások helyénvalóak, kijelölhetjük a megrendelőlistához képest hiányzó figurális ábrázolások körét is: Saturnus, Flora, Venus Medici és Faunus egyalakos szobrát, valamint az Apolló és Daphne, A szabin nők elrablása többalakos kompozíciókat nem találjuk napjainkban a teremben. A figurális mitológiai ábrázolások eredeti elhelyezéséről szinte semmit nem tudunk, Kelemen Márton 1826-os leírása ezekről egyáltalán nem ejt szót. A fotográfia korát mindenesetre az emeleti galéria rövidebb oldalai mentén húzódó polcok tetején érték meg, napjainkban is itt állnak. Az első világháború előtti fotókon a kancellár portréja mögött Hercules és Anteus, valamint Venus alakja azonosítható (2. kép). 1940 után átellenben, az ajtók közötti polc egyik sarkán Rhea ülőszobra (4. kép), a másikon

${ }^{65}$ KiMPIÁn 2002, i. m. 313. Cat. 46.

${ }^{66}$ Kimpián 2002, i. m. 331. Cat. 24. 2011-ben megsemmisült.

${ }^{67}$ Nem lenne egyedi az eset, hiszen a Téka holdsarlós diadémmal ékes, tehát Dianát ábrázoló büsztje (KImPIÁN 2002, i. m. 313. Cat. 45) is valószínűleg a jegyzékben szereplő Venus-büsztöt „helyettesíti”, ismét jelezve azt, hogy a megvásárolt gyüjtemény végleges összetételében a megrendelőlistához képest történtek változások.

${ }^{68}$ KimPí́n 2002, i. m. 311. Cat. 26.

${ }^{69}$ Kimpián 2002, i. m. 313. Cat. 47.

70 Les monumens antiques du Musée Napoléon, dessinés et graves par Thomas Piroli, avec une explication par Mr. Louis Petit Radel... Tome III. Paris, 1805, 99. 


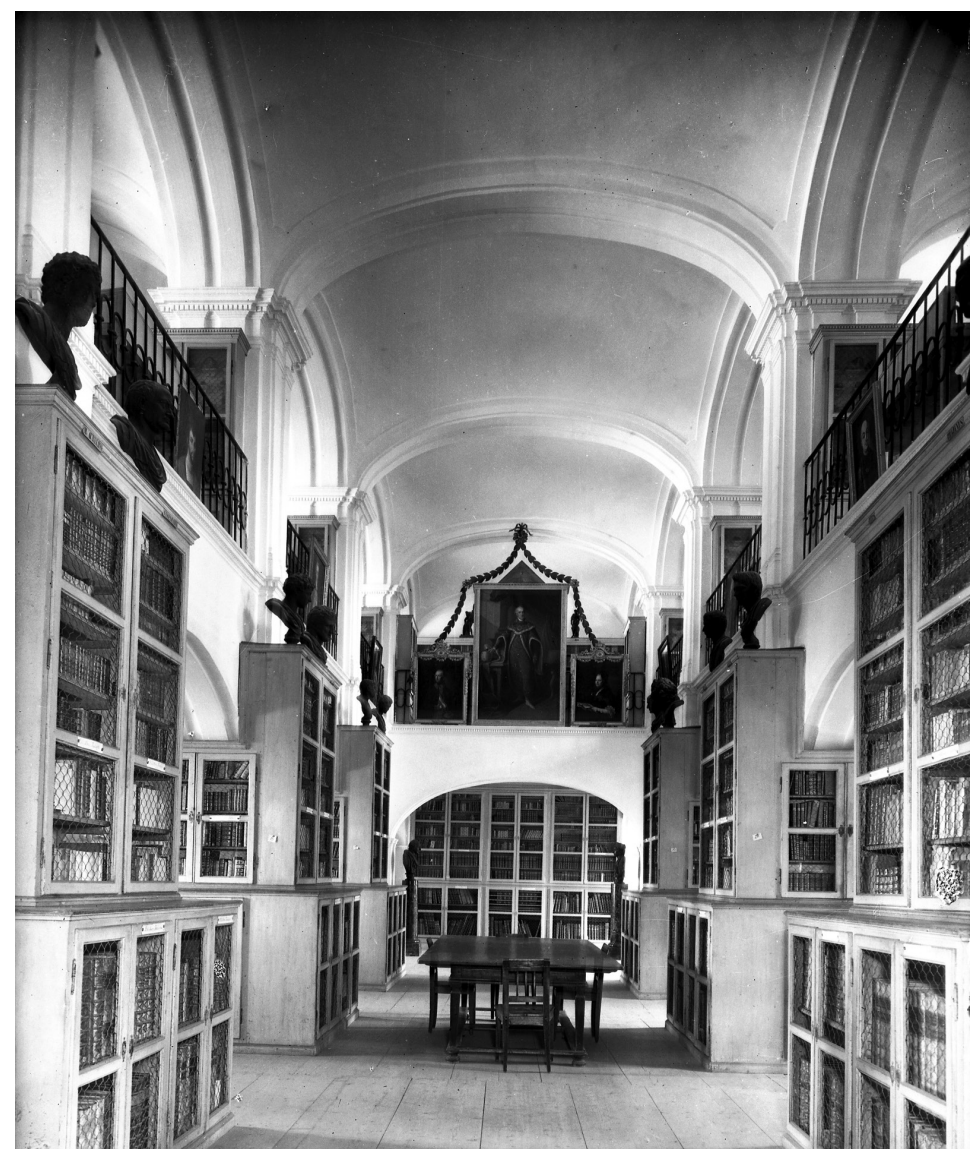

4. kép

Az ún. fegyveres szoba beépitett ajtaja a galérián 1940-1944 között (Az egykori Kulturális Örökségvédelmi Hivatal Fotótára, Budapest, $n r$. 28047)

a buzogányára támaszkodó Farnese-Hercules, középen talán a holdsarlós diadémmal ábrázolt Diana büsztje látható; a kancellár nagy portréja mögött továbbra is Hercules és Antaeus, valamint Léda (3. kép) és Bacchus szobra sejlik fel; ugyanitt a kert felöli sarokpolcon a Capitoliumi Antinóosz másolatának körvonalai vehetőek ki (5. kép).

Szintén Bécsben, Franz Thaller (1759-1817) mühelyében készült a kancellár és felesége jó müvészi minőségü, antikizáló bronz mellszobra. ${ }^{71} \mathrm{~A}$ tiroli származású Thaller a kor ismert bécsi szobrásza, 1802-től a császári Antikenkabinett munkatársa volt. ${ }^{72}$ 1802-ben vörös- és sárgaréz vásárlására kapott 200 rajnai fo-

71 DeÉ Nagy 1997, i. m. 224; KImpí́n 2002. i. m. 302-313.

${ }^{72}$ Allgemeines Lexikon der Bildenden Künstler von der Antike bis zur Gegenwart. XXXII. Band, 


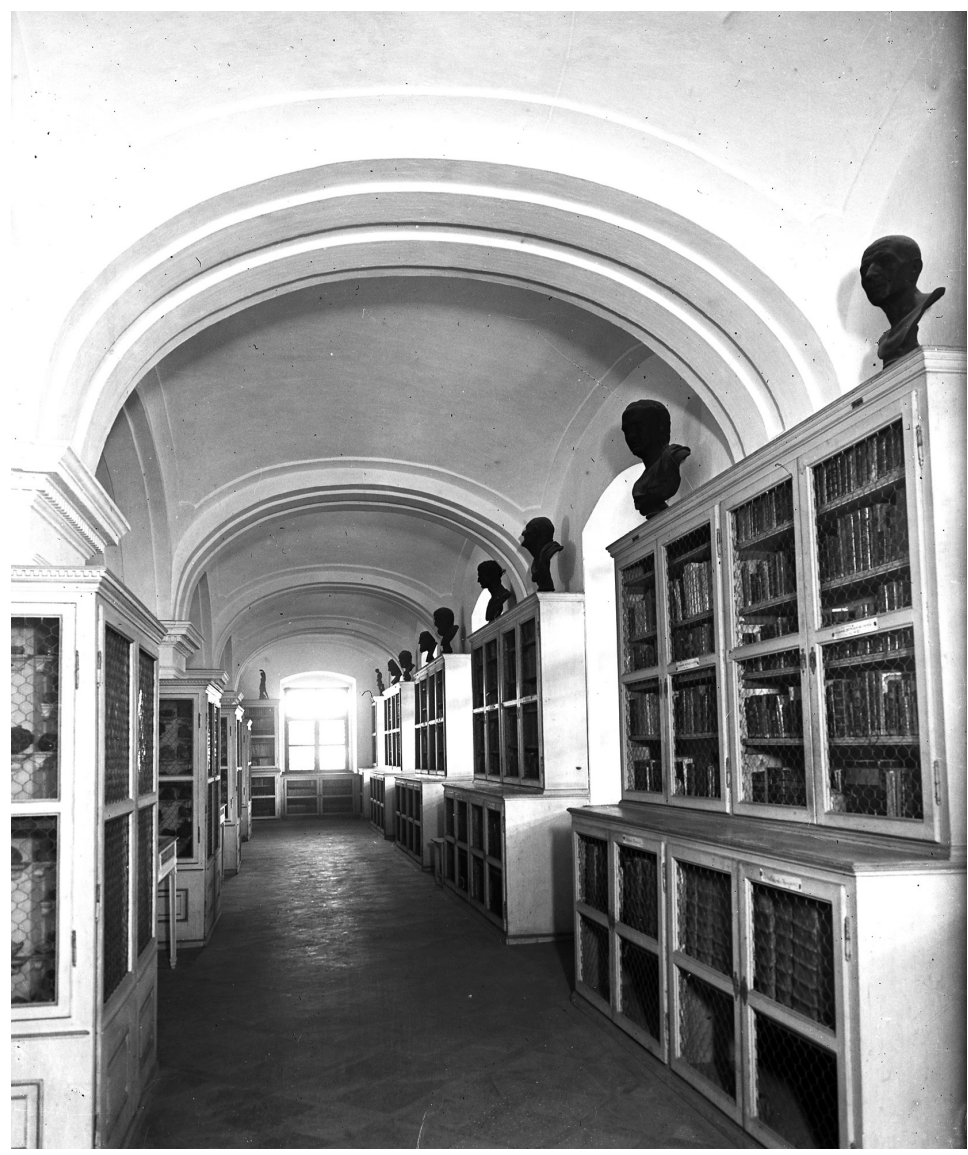

5. kép

A galéria 1940-1944 között. Balra az ásványtartó szekrények (Az egykori Kulturális Örökségvédelmi Hivatal Fotótára, Budapest, nr. 28042)

rintot Telekitöl, ${ }^{73}$ egy 1803 . július 10 -én kelt elismervény szerint pedig 500 rajnai forint előleget vett fel, kötelezve magát arra, hogy a kancellár mellképét újesztendőig, a feleségéét pedig legkésőbb jövő év április közepéig elkészíti. ${ }^{74} \mathrm{~A}$ munka a takarékos Teleki költekezési szokásait tekintve szokatlanul sokba, összesen 1500 rajnai forintba került, melyet a művész 1803-1805 között több részletben

begründet von Ulrich Thieme und Felix Becker, hrsg. von Hans Vollmer, Leipzig, Verlag von E. A. Seemann, 1938, 577.

73 Számla. Bécs, 1802. február 5. MNL OL, P 661, 24. cs. 1802. f. 1.

${ }^{74}$ Quittung. Bécs, 1803. július 10. MNL OL, P 661, 24 cs. 1803, f. 404. 
meg is kapott. ${ }^{75} \mathrm{~A}$ két büsztöt Thaller 1805 -ben szignálta. ${ }^{76} \mathrm{Az}$ idősödő kancellárt finoman redőzött, a bal mellén összetüzött köpenyben, hátrafésült hajjal, magas homlokkal, értelmet sugárzó, magabiztos tekintettel ábrázolta. A szobor készítésekor már nem élő Bethlen Zsuzsanna arckifejezése kevésbé életszerü, gazdagon redőzött ruhái - a derék felett átkötött tunica és a vállon átvetett palla - a római női viseletet idézik, hajkoronája pedig bizonyára a Flavius-dinasztia korának divatjából próbál ihletődni. A két portré Kazinczy figyelmét is felkeltette ottjártakor, megjegyezte, hogy Teleki arcmása ,itt is találva van”, Bethlen Zsuzsanna festmény után készült szobra viszont már kevésbé. ${ }^{77}$ Thaller egyébként ekkoriban más munkákat is végzett Teleki számára: 1803. szeptember 6-án négy darab, pontosabban meg nem nevezett gipsz mellszobor (,für vier verfertigte Büsten von Gyps") ellenértékeként 100 rajnai forintot vett át. ${ }^{78}$

\section{Ásványok, fegyverek, numizmák és régiségek}

Kétségtelen, hogy a könyvek mellett a legfontosabb kollekció az ásványgyüjtemény volt, mely a terem galériáján, a pillérek köré készített kétszáz éves szekrényekben máig fennmaradt. Jelentőségének köszönhetően az újabb kori kutatás figyelme is messzemenően kiterjedt rá: alapvetőek a témában Deé Nagy Anikó, ${ }^{79}$ valamint Viczián István írásai. ${ }^{80}$ A gyüjtemény alapjait Teleki Domokos (1773-

75 További számlái: 1804. március 23 és december 14. (MNL OL, P 661, 25 cs. 1804, 246, 247.) és 1805. április 20. (MNL OL, P 661, 27. cs. 1805, 2.)

${ }^{76}$ A keskeny bronztalapzatukhoz csavarral rögzített, elforgatható szobrok mellrészének alsó peremén található a mester szignója: „F. THALLER/TYROLENSIS. FEC. /VINDOB. MDCCCV” (a Teleki Sámuel szobrán lévő változatban: „...TYROLENSI...”)

77 KaZINCZY 1831, i. m. 572.

${ }_{78}$ Quittung. Bécs, 1803. szeptember 6. MNL OL, P 661, 24. cs. 1803, f. 407.

79 DeÉ Nagy Anikó, Ifjú gróf Teleki Domokos = Erdélyi Múzeum, 56(1994), 1-2, 25-50; DeÉ NaGY Anikó, Ásványok a könyvek között, Teleki Domokos és Teleki Sámuel ásványgyüjteménye a Teleki Tékában = Uö, Gondolatok a marosvásárhelyi Teleki Tékából, Tanulmányok, előadások, cikkek, Csíkszereda, Pallas-Akadémia, 2007, 34-53.

${ }^{80}$ Magyarul: Viczián István, Teleki Domokos elnöksége a jénai Ásványtani Társulatban a korabeli levelezés tükrében = Múzeumi Füzetek, Az Erdélyi Múzeum-Egyesület Természettudományi és Matematikai Szakosztályának Közleményei, Új sorozat 7(1998), 3-19; Az ásványtan iránti érdeklödés a németországi egyetemeken tanuló erdélyi diákok között a 18. század végén = Egyház, társadalom és müvelödés Bod Péter (1712-1769) korában, szerk. Gudor Botond, Kurucz György, Sepsi Enikő, Budapest, Károli Gáspár Református Egyetem, L’Harmattan, 2012, 108-121; Teleki Domokos és a Jénai Ásványtani Társaság = Formációk és metamorfózisok. A geológia, a filozófia és az irodalom kölcsönhatásai a 18-19. században, szerk. Gurka Dezső, Budapest, Gondolat, 2013, 124-137. - Idegen nyelven: István VICZIÁN, Letters of German naturalists to Domokos Teleki, first president of the Jena Mineralogical Society (dated 1796 to 1798) = Acta GGM Debrecina, Geology, Geomorphology, Physical Geography Ser. 4-5(2010), 75-87; Viczián István, Dé́ NaGy Anikó, Domokos Teleki, der erste Präsident der ,, Societät für die gesammte Mineralogie zu Jena” = Deutsche und ungarische Mineralogen in Jena. Wissenstransfer an der Wende des 18-19. Jahrhunderts 
1798), a kancellár idősebb fia vetette meg, aki kora ifjúságától tudományos igénynyel érdeklődött a mineralógia iránt, ásványgyüjteményét maga rendszerezte. Az egyetemi tanulmányait Bécsben végzett ifjú későbbi utazásai során 1795 őszén Drezdában, Lipcsében, Coburgban és Jénában is megfordult, ${ }^{81}$ utóbbi egyetemén Johann Georg Lenzcel, a mineralógia professzorával is megismerkedett. Jénában ekkoriban nagy számban tanultak magyarországiak és erdélyiek, az erdélyi lelöhelyek az európai mineralógiai érdeklődés homlokterében álltak, érthető tehát, hogy a kiváló felkészültségủ fiatal grófot az 1797 végén alakult Jénai Ásványtani Társaság első elnökévé választották. Domokos munkásságát - aki Kazinczy szerint ,idővel második atyja fogott volna lenni”"82 - korai halála törte derékba, azonban az ásványok gyüjtése halálával nem szünt meg. Atyja, aki 1802-től maga is a Jénai Ásványtani Társaság tiszteletbeli tagja volt, ${ }^{83}$ komoly erőfeszítéseket tett a gyüjtemény gyarapítására. Kihasználva udvari pozícióját, 1803-ban körlevélben igyekezett a bányahivatalokon keresztül a Habsburg Birodalom tartományaiból ásványokat szerezni, számottevő sikerrel. ${ }^{84}$ 1804-ben 22 láda ásványt szállítottak Bécsből Marosvásárhelyre, de további adományok is érkeztek, Hene Ferenc 1809-ben és 1813-ban küldött több láda ásványt, Lázár János guberniumi titkár is adományozott néhány darabot; a kollekció elhelyezése a polcokon 1814 után történt meg. ${ }^{85}$ Ezzel párhuzamosan zajlott a gyüjtemény szakszerü rendszerezése, kéziratban maradt katalógusát 1816-ra Hene Ferenc gyulafehérvári kanonok, kerci apát készítette el ${ }^{86} \mathrm{~A}$ jelentős tudományos teljesítménynek tekinthető mủ négy osztályba (földek-kövek, sók, gyúlékonyak, ércek) sorolva, latinul, németül, franciául és magyarul írja le a gyủjtemény darabjait, feltüntetve származási helyüket. 1816-ban készült supplementuma a „kősziklák” („saxa”) kategóriával bővítette a katalógust, a minták darabszáma ezekkel együtt majdhogynem megközelítette a 2500-at. A kéziratban a nagyszámú erdélyi lelőhely mellett két, a Nyugati-érchegységben található, Detunata Goală nevü bazalthegyet ábrázoló tusraj $z^{87}$ hangsúlyozza a mineralógia lokális dimenzióit. A munkát egy négynyelvü rendszertani tábla egészíti ki. A gyüjtemény Tékán belüli súlyát jól jelzi, hogy a kancellár figyelme könyvtárosai ásványtani képzésére is kiterjedt: az első könyvtáros, Szász József munkáját megszakítva épp a jénai egyetemen tanult, sőt, 1808. november 10-én a Jénai Ásványtani Társaság titkára lett (elnöke ek-

im Rahmen der ,, Societät für die gesammte Mineralogie zu Jena”, hrsg. Dezső Gurka, Budapest, Gondolat Verlag, 2015, 31-48.

${ }^{81}$ Az útvonalat feljegyzéseiben maga adja meg (vö. DeÉ NAGY 1994, i. m. 31), lásd még 1795ös leveleit (MNL OL, P 661, Missiles, Nro 1849-1856, illetve 1825).

${ }^{82}$ KazincZy 1817, i. m. 5.

${ }^{83}$ Diplomája: MNL OL, P 661, 24. cs. 1802, f. 153.

${ }^{84}$ MNL OL, P 661. 24. cs. 1803, f. 545-546, passim.

${ }^{85}$ A Teleki család sáromberki levéltára a Kolozsvári Állami Levéltárban, 17. cs. f. 77.

${ }^{86}$ Consignatio Methodica Fossilium, in celebri Bibliotheca ab Excellentissimo ac Illustrissimo Domino Samuele e Comitibus Teleki de Széék... Teleki-Bolyai Könyvtár, Tq-881 b/2 MS. 319.

${ }^{87}$ Jelezve jobbra lent: „Reinbold”. 
koriban maga Goethe volt). ${ }^{88}$ Nyilvánvaló, hogy a gyüjtemény a 18-19. század fordulóján, ha rövid időre is, de az európai ásványtan tudományos élvonalába emelte Marosvásárhelyt, hatásában tehát méltó volt a könyvtár jelentőségéhez.

A fegyverek gyüjtése igen elterjedt volt a kor foúri társadalmában, ez alól pedig az amúgy nem túl harcias kancellár sem képezett kivételt: méltatlanul elfeledett fegyvergyüjteménye értékes, rendezett, és minden jel szerint a szívéhez közel álló kollekció volt. Több körülmény utal erre: kezdettől külön termet szánt ennek a galéria és saját hálószobája között, melybe 1802-ben speciális tárlókat rendelt, ${ }^{89} 1805$-ben pedig saját kezüleg állította össze a gyüjtemény leltárát, ${ }^{90}$ mely a későbbiekben a nyilvántartás alapját képezte. ${ }^{91}$ Ez a tárgyakat öt osztályba soroló jegyzék a mára teljesen szétszóródott gyüjtemény összetételének becses forrása. A pisztolyok 34 tétele alatt kivétel nélkül egy-egy pár fegyvert vett számba, a puskák (,flinták”) sorában 42, a karabélyok („,stutzok”) csoportjában 7 darabot találunk, a lőfegyverek száma tehát összesítve jócskán meghaladta a százat. Sok közöttük az arannyal, ezüsttel díszített, „virágos mettzésü”, elefánt- vagy teknősbéka-csont agyú, míves alkotás. A „más egyéb fegyverek és páltzák” közé zömmel szúró- és vágófegyverek (török handzsárok, vadásztőrök), díszkardok, puskaportartók és pálcák kerültek, valamint olyan érdekességek, mint egy tatár nyíl, ,ezüsttel egészen béborított, aranyos virágos buzogány”, „,hal-forma, szépen ki-mettzett, figurás, elefántcsont puskapor tartó”, „tengeri csiga rezes vadászkürt”, ,páva tolluból kötött kocsis korbács” (összesen 71 tétel). A lószerszerszámok között nyergek, takarók, díszes kantárok, zablák, kengyelek szerepelnek (34 tétel), jelenlétüket Teleki Sámuel utókor számára kevéssé ismert, lovak és lótartás iránti élénk érdeklődése magyarázza.

A lőfegyverek tekintélyes része mesterjeggyel bírt: a bresciai Cominazzo fegyverkovács dinasztia, a carlsbadi Anton Sebert és Taddeus Poltz, a linzi Anton Bell, a bécsi [Joseph] Wedelmayr (Weindlmayr) és Ignaz Klein, Joseph Qualek, Andreas és Jacob Kuchenreiter, Maffeo Francino, Joseph Plauer, Rovi-

${ }^{88}$ Teleki Sámuel személyi levéltár, Teleki-Bolyai Könyvtár, nr. 897, 898.

${ }^{89}$ „Szép fegyver tartó Thécákat fejér Firneis festékkel sárga párkányokkal az eggyik szegelettől fogva a másikig végig a fal mellett, az stakatura párkányáig való magosságra; nem külömben a kert felől a két ablak közé jó rezes zárokkal. Magasságok légyen az stakatura párkányáig. A Thécák ajtaji pedig légyenek alól két Schuchnyira blindfellungal, azon felyül kívül sárga vas rostély drótból, és azon belőll üveg táblák. A mélysége légyen a Thécáknak egy Schuch." Lásd Pro memoria. Kiadtam inspectoromnak, Kadácsi úrnak. Marosvásárhely, 1802. október 2. A Teleki család sáromberki levéltára a Kolozsvári Állami Levéltárban, 833. cs. A gyűjtemény még jóval kevesebb tételt számláló, első leltára épp ezzel a rendelkezéssel egyidőben keletkezett, végére a kancellár saját kezüleg jegyezte fel, pont a könyvtárnyitás napjaiban, hogy „Által adtam e szerént Herbert Mihály számtartómnak gondviselése és számadása alá M[aros]Vásárhelyen. 15a oct. 1802.” Teleki Sámuel személyi levéltár, Teleki-Bolyai Könyvtár, nr. 852.

${ }^{90}$ Közli: Dékáni Kálmán, Gróf Teleki Sámuel fegyvergyüjteménye = Hadtörténelmi Közlemények, 16(1915), 219-225.

${ }^{91}$ A Téka levéltára a leltár számos későbbi változatát őrzi, ezek alapját kivétel nélkül Teleki 1805-ös jegyzéke képezi. 
ra, Guiot, Repoll, Fruchwirth, Becker, Jo[seph] Spirkenbickler (Spirckenpichler) neve azonosítható a leltárakban. ${ }^{92}$ Több fegyver Teleki neves kortársaié volt. Ilyenek a Vincenz von Barco (1719-1797) lovassági tábornoktól, Johann Franz Preiss (1704-1797) táborszernagytól, Erdély egykori főhadparancsnokától, vagy a Wenzel Anton von Kaunitz (1711-1794) kancellártól származó pisztolyok. Ernst Gideon von Laudon (1717-1790) tábornagytól, a kiváló osztrák hadvezértől egy pár ezüstözött pisztolyt, valamint egy Ramsden-távcsövet, Joseph Nikolaus de Vins (1732-1798) táborszernagytól, az első koalíciós háború egyik észak-itáliai parancsnokától és Alvinczi József (1735-1810) tábornagytól, több Napóleonnal vívott csata (Bassano, Caldiero, Arcola, Rivoli) hősétől további pisztolyokat őrzött Teleki. Egy aranyozott kard a marengói csatában elesett francia tábornok - bizonyára a csata kimenetelét eldöntő Louis Desaix (1768-1800) fegyvere volt. Egy arany gombos nádpálcáról azt jegyzi meg a kancellár, hogy a genovai követé volt. Apafi Mihály erdélyi fejedelem aranyos kopjája és Rákóczi fejedelem arannyal varrott börtarsolya már történeti értéke miatt érdemelte ki helyét a polcokon.

Levéltári adatok utalnak arra, hogy a fegyvergyüjtemény termét nyilvános térként és nem a fớri magánlakosztály részeként kezelték, a látogatók ide is beléphettek, esetenként károkat okozva ${ }^{93}$ A gyüjtemény azonban nem a mai értelemben volt muzeális jellegü: java része müködő fegyver volt, melyet esetenként használtak is. Több pisztoly mellett maga a kancellár jegyezte meg, hogy utazáskor magával hordja, vagy épp Bécsben tartja, néhány fegyvert számtartójának adott át, többet fia, Ferenc vagy épp ennek felesége számára emeltek ki szükség esetén a tárlókból; a díszöltözetekhez használt kardok java része is nyilván Bécsben volt 1805-ben. ${ }^{94} \mathrm{~A}$ gyüjtemény státusának eme kettősségét érzékelteti nemcsak alaprajzi helyzete (a hálószoba és könyvtárterem között, a nyilvános és magán terek határán), hanem az is, hogy a lakószobák ingóságaival együtt következetesen a városi palota gondviselöinek számadása alá kerültek.

A fegyverek müködőképessége a gyüjtemény vesztéhez is hozzájárult: az 1848-1849-es forradalom idején a városban megforduló seregek dézsmálták meg az állományt. Berzenczey László főbiztos 1848. október 29-én kelt rendelete következtében Kelemen Márton könyvtáros kénytelen volt „vadászcsapatának” 16 darab használható lőfegyvert jegyzék mellett kiosztani, így név szerint tudjuk, hogy az egység két tagja a kancellár régi Spirkenbicklereivel, hatan pedig a carlsbadi Poltz fegyverkovács bizonyára kissé már ódivatú míves puskáival vonultak hadba ${ }^{95}$ Később a császári katonatisztek a becsesebb darabokat ládákban hordták

92 Átírásukban igyekeztünk összevetni különböző időszakokból fennmaradt leltárak névváltozatait.

93 Teleki Sámuel személyi levéltár, Teleki-Bolyai Könyvtár, nr. 130.

94 Teleki Sámuel személyi levéltár, Teleki-Bolyai Könyvtár, nr. 126.

95 Teleki család sáromberki levéltára a Kolozsvári Állami Levéltárban, 17. cs. f. 125-126. 
el. ${ }^{96}$ 1915-ben Dékáni Kálmán már csak csekély részüket láthatta, napjainkban egyetlen fegyver sincs az épületben.

A kancellár a könyvtár ékességének szánta numizmatikai gyüjteményét is, bár Kazinczy tudomása szerint ez 1816-ban még nem érkezett le Marosvásárhelyre. ${ }^{97}$ Halálakor még mindig számos, a könyvtár hitbizományához rendelt érmét vettek számba Bécsben, ékszerek, drágakövek és szelencék társaságában. ${ }^{98} \mathrm{Nem}$ tudjuk, hogy a gyüjtemény kialakulása hány évtizedet ölelt fel, első részletes jegyzékét mindenesetre 1808-ból ismerjük, és az ezt követő években is rendszeres a gyarapodás. Az utolsó hat darab, Hunyad vármegyében talált római ezüstpénzt halála évében, 1822-ben jegyezte be a leltárba - már erősen reszkető kezekkel - az agg kancellár. Főként értékes római érméket, magyar és császári, valamint „idegen” pénzeket tartalmazott, de nagy számban fordultak elő benne a koronázások, udvari házasságok, különféle kortárs események (a császári pár erdélyi látogatása, a bécsi Polytechnikum alapítása, a reformáció 300. évfordulója, a bécsi Nemzeti Bank vagy az esztergomi székesegyház alapkőletétele stb.) alkalmából kibocsátott emlékérmék. Java részük arany és ezüst, de volt közöttük rézpénz is, öszszesített számuk a kancellár halálakor meghaladta a 330-at. ${ }^{99}$ Látnunk kell, hogy a zömmel nemesfémekből álló kollekció nemcsak Teleki gyüjtési szenvedélyét elégítette ki, hanem bizonyos mértékben a vagyon tezaurizációjának eszköze is volt - nem véletlen, hogy a család ékszerei, arany- és ezüstnemüi között vette számba. A gyűjtemény értéke a későbbiekben hozzájárulhatott sorsa ellentmondásos alakulásához is: a kancellár fia, Ferenc 1823-ban sáromberki kastélyába vitte, ${ }^{100}$ 1852. április 4 -én kelt végrendeletében pedig még mindig úgy beszél róla, mint amit halála után vissza kell majd csatolni a Téka hitbizományához, a szintén oda tartozó drágakövek („,gyürü-fő collectio”), szelencék („,kő pixis collectio") egy diadém, egy handzsár és két nyeregszerszám táraságában. ${ }^{101} \mathrm{Nem}$ tudni, hogy ez a gyüjtemény elfoglalta-e valaha az ôt megillető helyet a hanyatlófélben lévő könyvtárban.

Benkő Károly 1862-ben régiséggyüjteményt emleget, melyet a kancellár egészalakos portréja mögötti fiókos szekrényben tároltak, megjegyezve, hogy a római régiségek száma ezek között csekély. ${ }^{102} \mathrm{~A}$ kancellár nyilván érdeklődött az antikvitás Erdélyben szép számban fellelhető tárgyi emlékei iránt is - 1803-ban római feliratos kövek leszállításáról levelezett, ${ }^{103}$ éremtárába 1818-ban Tordán, 1822-ben Hunyad vármegyében talált római ezüstöket szerzett -, ám ez a gyüjte-

${ }^{96}$ BENKÖ Károly, Marosvásárhely szabadi királyi város leírása 1864-ben, s. a. r. Pál-Antal Sándor, Marosvásárhely, Mentor, 2001, 23.

97 KazINCZY 1817, i. m. 7.

98 Teleki család sáromberki levéltára a Kolozsvári Állami Levéltárban, 17. cs. f. 109-124.

99 Teleki Sámuel személyi levéltár, Teleki-Bolyai Könyvtár, nr. 122.

100 Teleki Sámuel személyi levéltár, Teleki-Bolyai Könyvtár, nr. 138.

101 Teleki család sáromberki levéltára a Kolozsvári Állami Levéltárban, 17. cs. f. 206-207.

102 BENKÖ 2001, i. m. 23.

103 Teleki Sámuel Szász Józsefhez. Bécs, 1803. július 26. Közli DeÉ NAGY 1997, i. m. 345. 
mény a jelek szerint nem teljesedett ki. Az antikvitás és a régiségek iránti elmélyült érdeklődésének valódi emlékeit könyvtárában lelhetjük fel. A gyüjtemény VI. osztályát képező 'Bibliotheca Antiquaria' ugyanis látványos mennyiségü könyvet vonultat fel: kilenc alosztály foglalja magába az egyiptomi és keleti, a görög, római régiségek, a mitológia, a felirattan és a numizmatika régi és új irodalmát, ugyanakkor nagy súllyal vannak jelen az antikvitás tárgyi emlékeit bemutató albumok. ${ }^{104} \mathrm{Az}$ osztály fontosságát jelzi a könyvtáron belül, hogy a nyitást követően is igen nagyszámban érkeztek ide az új szerzemények, közöttük a látványos Piranesi-kiadványok, és nem utolsó sorban egy jelentékeny gipsznyomat kollekció. ${ }^{105} \mathrm{~A}$ több száz címet magába foglaló állomány tehát egyaránt szolgálta a tudományos igényü elmélyülést, valamint a szemléltetést, mind gazdagságát, mind minőségét tekintve európai színvonalon.

Teleki Sámuel kezdettől számolt könyvtára mellett kiegészítő gyüjteményekkel: az intézmény szabályzata 1798-ban a múzeum nyilvánosságáról is rendelkezett. Ezek azonban alárendelt szerepet játszottak, kialakulásukban így kisebb mértékben érvényesült a tervszerüség és a céltudatosság. Látnunk kell azt is, hogy a képzőművészeti alkotások beszerzését nem annyira a szisztematikus mügyüjtés, mintsem a könyvtár ékesítésének szándéka sarkallta, a portrékat különféle forrásokból válogatták a nyitást követő években, a gipszmásolatok a terem díszítésének egyszeri alkalommal vásárolt, olcsó eszközei voltak. Értelmezésükhöz is inkább a terem ikonográfiája, mintsem a gyüjtéstörténeti kontextus kínál fogódzókat: a könyvtáralapítók és ókori nagyságok együttesen keltik életre a csarnok szellemiségét, a közjó és a tudásba vetett hit eszményét; de értő közönséget biztosítanak a középpontban fenséges portrén megjelenő, a tudás templomát áldozatos munkával megteremtő felvilágosult arisztokrata apoteózisához is.

A legfontosabb kollekció, a rendszeres gyüjtés eredményeként létrejött tárgysorozatokat tartalmazó ásványgyüjtemény összeállítása és elhelyezése már figyelemre méltó tudományos körültekintéssel, szakemberek bevonásával zajlott. Az alapító szándéka szerint a könyvtárba került volna éremgyüjteménye is, mely szelencékkel és drágakövekkel egészült ki. A külön teremben megszemlélhetö fegyvergyüjtemény a míves darabok, személyes emléktárgyak mellett néhány kuriózumot is felvonultatott. A könyvek és más kollekciók hasonló, a Kunst- und Wunderkammer hagyományától sem teljesen idegen együttélése egyébként máshol is megfigyelhető ekkoriban Erdélyben, Brukenthal Sámuel gubernátor szebeni palotájában a képtár mellett könyvtár, érem- és ásványgyüjtemény, római leletek kaptak helyet. Példája közvetlenül is hathatott Telekire, aki az 1770-1780-es években guberniumi tanácsosként Szebenben közelről szemlélhette a palota berendezésének folymatát. Számolnunk kell a bécsi udvari környezet, a 19. század

${ }^{104}$ Bibliothecae Samuelis S. R. I. Com. Teleki de Szék Pars secunda, Viennae, typis Mathiae Andreae Schmidt, 1800, 309-330.

105 Teleki 1803-ban Bécsben Carl Ackermanntól másfél ezernél is több gipsznyomatot vásárolt, bizonyára Sebastian Hess Daktyliothekájának darabjait. MNL OL, P 661, 24. cs. 1803, f. 408-409. 
elején virágkorát élő császári Münz- und Antikenkabinett hatásával is, arról nem is beszélve, hogy a Téka legkvalitásosabb müalkotásait készítő múvészek (Thaller, Tusch) is ebböl a közegből kerültek ki.

\section{ORBÁN, JÁNOS}

\section{The library and the collections of Sámuel Teleki}

Our summary presents the art historic values of one of the most important public libraries, the Teleki Téka, located in a Hungarian language area, which opened its gates in 1802, in Tîrgu Mureș. The three-nave library hall was built between 1799 and 1802, based on the improved plans of Ernest Koch from Vienna. The customer, Count Sámuel Teleki (1739-1822), the chancellor of the Great Principality of Transylvania, also set up a portrait gallery in the great hall of the library, in which first of all, his renowned contemporaneous book collectors and ancestors received a place. The gypsum statues ordered from Vienna display mainly the great figures of Antiquity and mythology. Franz Thaller prepared the bust of the count and his wife in the same place. The rich collection of minerals, which was compiled by the founder and his son Domokos, can be found even today in the library. Nevertheless, the once spectacular weapon and numismatic collection was unfortunately dispersed during the centuries.

Keywords: Samuel Teleki; Teleki Library; library architecture; historical library; art collection 